\title{
GOVERNMENTAL INTEREST AND THE CONFLICT OF LAWS-A REPLY TO PROFESSOR CURRIE
}

\author{
AIFREd HIIL*
}

TN A sERIEs of articles published in this and other journals, ${ }^{1}$ Professor Brainerd Currie has proposed the scrapping of traditional methods of choice of law in favor of a system involving the effectuation of relevant governmental policies on what appears to be an ad hoc basis.

He sees the traditional goal of the law of the conflict of laws as the uniform resolution of a controversy irrespective of the place of trial. He concedes the value of such uniformity in various types of cases, but thinks the courts ought to abandon their attempts to achieve it. In the pursuit of uniformity, he says, the courts are instructed by the "taught system of choice of law" to function as automatons-to adjudicate upon the basis of "talismanic" 3 contacts such as place of contracting or place of wrong, without regard to whether the outcome of such adjudication is sense or nonsense. The consequence, he says, is that the interests of the forum may be subverted in favor of the interests of a foreign state, or, worse still, the interests of the forum may be subverted without advancing the interests of any other state-and he apparently believes. that such results are characteristically produced by the "taught system."

His conclusion is that "we would be better off without choice-of-law rules."

* Professor of Law, Northwestern University.

-1 Married Women's Contracts: A Shudy in Conflict-of-Laws Method, 25 U. CEI. L. Rev. 227 (1958); Survival of Actions: Adjudication versus Automation in the Confict of Laws, 10 StaN. L. REv. 205 (1958); The Constitution and the Choice of Law: Grvernmental Interests and the Judicial Function, 26 U. C\#I. L. REv. 9 (1958); Notes on Methods and Objectives in the Contict of Laws, 1959 Duke L.J. 171; On Displacement of the Law of the Forum, 48 Color. L. REv. 964 (1958); The Constitution and the "Transitory" Cause of Action, 73 HARv. L. Rev. 36 (Part I), 268 (Part II) (1959); The Silver Oar and All That: A Study of the Romero Case, 27 U. CHI. L. REv. 1 (1959); Purchase-Money Mortgages and State Lines: A Study in Conflictof-Laws Method, 1960 DuKe L.J. 1 (with Mark S. Lieberman); Change of Venne and the Conftict of Lares: A Retraction, 27 U. CEr. L. REv. 341 (1960). Also see his review of EHREN2WEIG'S CONFLICT OF LAWS in 73 HARV. L. Rev. 801 (1960).

The first four of the articles seem to this writer to set forth Professor Currie's thesis rather completely. They are the articles most frequently cited in this paper, and in subsequent references to them only the volume and page numbers will be indicated. The remaining articles consist of additional case studies in the analysis of government interest, or explorations of certain problems raised by Professor Currie's suggested approach to the matter of choice of law; they will be referred to from time to time where relevant to the discussion of the central thesis. See note 48 infra.

210 STAN. L. REv. at 241.

, 26 U. CHI. L. Rev. at 10.

41959 Duke L.J. at 177. 
Having given up attempts to square the circle, he says, we should give uf attempts to work out a rational system of choice-of-law rules, and for essentially the same reason: "the task is impossible of accomplishment with the resource: which are available." In the future, he urges, let the courts of a state adjudicat a controversy in a manner which rationally advances the interests of that state if these be lacking, then let the courts advance the interests of some other state which does have substantial interests at stake. The quixotic quest for uniformity should be abandoned by the courts. He recognized that his proposal is not "ideal,"6 and that it would actually prevent uniformity in situations where uniformity may be desirable. But he believes that this is a matter which should be dealt with by legislation-specifically, federal legislation; the courts are not equipped to resolve such problems, and in any event it is not consistent with our philosophy of government that they should assume this task.

There follows, in his own language, Professor Currie's prescription of a desirable conflict-of-laws method:

1. Normally, even in cases involving foreign factors, a court should as a matter of course look to the law of the forum as the source of the rule of decision.

2. When it is suggested that the law of a foreign state, rather than the law of the forum, should furnish the rule of decision, the court should first of all determine the governmental policy-perhaps it is helpful to say the social, economic, or administrative policy-which is expressed by the law of the forum. The court should then inquire whether the relationship of the forum state to the case at bar-that is, to the parties, to the transaction, to the subject matter, to the litigation-is such as to bring the case within the scope of the state's governmental concern, and to provide a legitimate basis for the assertion that the state has an interest in the application of its policy in this instance.

3. If necessary, the court should similarly determine the policy expressed in the proffered foreign law, and whether the foreign state has a legitimate interest in the application of that policy to the case at bar.

4. If the court finds that the forum state has no interest in the application of its law and policy, but that the foreign state has such an interest, it should apply the foreign law.

5. If the court finds that the forum state has an interest in the application of its laws and policy, it should apply the law of the forum even though the foreign state also has such an interest, and, a fortiori, it should apply the law of the forum if the foreign state has no such interest. ${ }^{7}$

The thesis thus boldly advanced has already been the subject of considerable comment by legal scholars, ${ }^{8}$ much of it favorable. At the 1958 Convention

525 U. Chr. L. Rev. at 263.

- 10 Stan. L. Rev. at 245.

226 U. CHr. L. Rev. at 9-10.

${ }^{8} \mathrm{Kramer}$, Interests and Policy Clashes in Confict of Iaws, 13 RUTGers L. Rev. 513 (1959); Traynor, Is This Conflict Really Necessary? 37 Tex. L. REv. 657, 667-75 (1959); Kelso, The Process of Analyzing Choice of Law Problems, 1959 Wasr. Unw. L.Q. 37; Sumner, Choice of Law Rules: Deceased or Revised? 7 U.C.L.A. L. Rev. 1 (1960); Leflar, Conflict of Laws (Annual 
of the Association of American Law Schools, Professor Currie's thesis was the sole subject considered at the round table meeting on the conflict of laws; 9 attendance was heavy, and again much of the comment was favorable. A writer on international law, commenting on the prospects of American participation in certain international efforts now afoot to standardize, by treaty or model legislation, the choice-of-law rules applicable to international contracts, has noted that the current climate in the United States is particularly unreceptive to such participation, and has emphasized in this connection the "new ferment" created by Professor Currie's writings: "Professor Currie's approach ... is now part of the common currency of conflict of laws controversy, and upon the strength of it there would ... be resistance to solutions which ignored it."10

It is proposed in this paper to examine (1) Professor Currie's purported demonstration of the inadequacy of the traditional system; (2) the system he would substitute in its place; and (3) the role of governmental interest as a criterion for the solution of choice-of-law problems.

\section{The Purported Demonstration of the Inadequacy of the Traditional System}

As far as the reader can judge, 11 Professor Currie's views seem to be based upon two case studies: one in contract ${ }^{12}$ and the other in tort. ${ }^{13}$ In each instance he has constructed a number of hypothetical controversies; he has considered the outcome of these controversies under the assumed application of traditional choice-of-law rules, as embodied in the Restatement, ${ }^{14}$ and he has measured the results against his own ideas as to what a desirable outcome would have been. Thus viewed, the results are appallingly bad, and from this seems to stem his conclusion with respect to traditional choice-of-law rules generally that they "have not worked and cannot be made to work." 15 Professor Currie appears to recognize the utility of choice-of-law rules which, though imperfect, are at least

Survey of American Law), 35 N.YU.L. Rev. 62, 63-66 (1960). Cf. Oliver, Standardization of Choice-of-law Rules for International Contracts: Should There Be a New Beginning?, 53 AM. J. of INT'I L. 385, 388-89 (1959); Note, 108 U. PA. L. Rev. 742, 746-47 (1960); Note, 45 Iowa L. Rev. 608, 613 (1960); Note, 32 Rocky MT. L. Rev. 238 (1960). See also EHRENZwEIG, Conflict of Laws 16 (1959); Ehrenzweig, The Real Estale Broker and the Conflict of Laws, 59 ColuM. L. Rev. 303, 304-5 (1959); Ehrenzweig, The Lex Fori in the Conflict of LawsException or Rule?, 32 Rockx Mr. L. REv. 13 (1959); Ehrenzweig, The Lex Fori-Basic Rule in the Conflict of Laws, 58 MrCH. L. REv. 637 (1960).

'Association of American Law Schools, 1958 Proceedings 281. The reference is to the program of the meeting; the round table discussion has not been published.

${ }^{10}$ Oliver, supra note 8 , at $388,389$.

"See note 48 infra.

1225 U. CHI. L. REv. at 227.

1310 StaN. L. REv. at 205.

I4 REsTatement, Conflict of Laws (1934).

151959 DUKE L.J. at 174. 
workable and generally advance the public welfare in a rational manner even if at the cost of an occasional "bad" result. ${ }^{16}$ However, he believes he has demonstrated that such rules have not been achieved and cannot be achieved by the usual methods of the conflict of laws. The question we are here concerned with is the validity of this demonstration, and for this purpose we may accept, at least for the present, his judgments as to what comprises a desirable and what an undesirable result.

The most important article in his series is the first, ${ }^{17}$ containing as it does the essentials of his method and all his basic conclusions. The starting point of the analysis is the famous case of Milliken v. Pratt. ${ }^{18}$ Under the Massachusetts law of the time, married women did not have capacity to contract; under the law of Maine they did have such capacity. A married woman domiciled in Massachusetts had made a contract, as the court found, in Maine, with a Maine partnership, and thereafter was sued on the contract in Massachusetts. The holding was that she was liable, on the ground that "the validity of a contract is to be determined by the law of the State in which it is made... "19 The defense of public policy was rejected, apparently on the ground that after the making of the contract a statute had been enacted in Massachusetts removing the incapacity of married women. ${ }^{20}$

Professor Currie contends that it is irrational to look, as most courts apparently do, ${ }^{21}$ to the place of the making of the contract to determine the capacity of the parties. The policy of Massachusetts (and Maine) had to do, he says, with people, and more specifically with people who were the natural subjects of the sovereign interest of the state: to wit, its own residents. Both states were concerned with the security of commercial transactions, but Massachusetts, unlike Maine, was willing to subordinate this policy for the purpose of protecting those of its residents who were married women..$^{2}$ The controversy between a

${ }^{16}$ See 25 U. CHr. L. REv. at 247.

${ }^{17} \mathrm{Id}$. at 227.

${ }^{19} \mathrm{Id}$. at 375 .

18125 Mass. 374 (1878).

${ }^{20} \mathrm{Id}$. at 383 .

${ }^{21}$ See Goodrich, Conflict of Laws 312-16 (3d ed. 1949); Stumberg, Conflict of Laws 242 (2d ed. 1951). This is also the Restatement view: Restatenrent, Confuict of Laws $\S 333$ (1934).

22 Professor Currie does not take the position that the common law incapacity of married women was actually designed for the protection of such women. He notes that the purpose or policy of a common law rule may be "obscured by the mists of antiquity," $25 \mathrm{U}$. CHI. L. REv. at 230, and he does not explore the origin of this one. He assumes for purposes of his analysis that recent legislative events in Massachusetts had clearly demonstrated that the protection of resident married women was the reason for retention of the common law rule of contractual incapacity.

Apparently the origin of this rule lay in the circumstance that the husband had ownership or control of what otherwise would have been the wife's independent estate. It is arguable that if anybody was intended to benefit from the rule it was the husband rather than the wife. Cf. 3 HolDsworth, A History of ENGIISH Law 520-30 (3d ed. 1923). On the other hand the rule operates for the direct benefit of the wife as she comes increasingly to enjoy the incidents of ownership. 
Maine partnership and a Massachusetts married woman was essentially a conflict between the interests of the two states. Massachusetts resolved this conflict, according to Professor Currie, by subverting its own interests and advancing the interests of Maine.

But much worse can and does happen, he says. Assuming the incapacity of married women to contract under the law of Massachusetts, he poses the problem of a contract made in Massachusetts between a Massachusetts creditor and a married woman who is domiciled in Maine. Here, according to Professor Currie, there is no conflict between the policies of the two states. The Massachusetts policy of providing a climate of security for commercial transactions entered into by its own residents is not qualified by a policy of protecting non-resident married women, and Maine has no policy of shielding its own married women from contractual liability. For a Massachusetts court to invalidate the contract by applying the law of the place of making would be to subvert the interests of Massachusetts without advancing any interest of Maine. This is an instance of what Professor Currie calls a false conflict, as distinct from the true conflict involved in the previous illustration.

Carrying the analysis further, he proceeds to explore what he considers to be the full potential of the Milliken v. Pratt situation. For purposes of the analysis he employs four contact points: 1 . The residence of the married woman. 2. The residence of the creditor. 3 . The place where the contract was made. 4. The forum. Any one or more of the contact points may be domestic (Massachusetts); any one or more of them may be foreign (Maine). The number of possible combinations is sixteen. In one of these all four are domestic; in another they are all foreign. These two cases are eliminated at the outset, leaving fourteen cases with mixed domestic and foreign elements. On the issumption that each of these cases will be decided in accordance with the law of the place where the contract was made, Professor Currie analyzes the results in light of what he assumes to be the practical interests of the states in each instance.

Of the fourteen cases, ten are false-conflict cases, and in no less than six of these the results are found to be "purely perverse"23 because the interests of one state are subverted without advancing the interests of the other. In the four cases where a true conflict exists, domestic interests are subordinated to foreign interests exactly half the time. ${ }^{24}$ In a similar connection, Professor Currie states: "One is almost tempted to suggest that it would be better to flip a coin, since that procedure would produce the same results more economically."25

Even if the system resulted in the desired uniformity, Professor Currie ques-

2325 U. ChI. L. REv. at 242, 246.

${ }^{24}$ Ibid.

262. 
tions whether this achievement is "worth the cost at which it was attained."26 We are told that the "startling"27 number of perverse results in the false-conflict cases and the haphazard results in the true-conflict cases represent "an extravagant price to pay for uniformity of result." ${ }^{28}$ The suggestion that there has been a demonstration of the "cost" of the traditional system appears more than once in the article $;{ }^{29}$ yet we have testimony from Professor Currie himself that his computation of costs in terms of bad results is no more than an artificial product of his mathematical model, and has little to do with the proportion of undesirable results produced by the actual operation of the system. ${ }^{30} \mathrm{~A}$ demonstration that undesirable results are reached in six or eight out of fourteen possible cases is a demonstration of what is theoretically possible; to compute the actual cost of the system we must know the relative frequency of such undesirable results. In one of Professor Currie's hypothetical cases, a Maine creditor sues a Massachusetts married woman in Massachusetts on a contract made in the same state; a desirable result is reached. ${ }^{31}$ In another of his cases a Maine creditor sues a Maine married woman in Maine on a contract made in Massachusetts; an undesirable result is reached. ${ }^{32}$ The relative frequency of the two types of cases is not considered; the two cases are given equal weight in Professor Currie's calculations. These calculations yield "startling" information about the "extravagant price" that is paid for uniformity under his assumptions; they leave us curious about the "price" that is actually paid.

But even if Professor Currie's tables were meaningful in terms of the relative frequency of the classes of cases considered, they would tell us little of the actual "cost" of the traditional system. Professor Currie is quite aware that judges do not uniformly act in the manner indicated by his tables. "As everyone knows," he says, the place-of-making rule, which "operates so capriciously" that it "seems almost incredible" that it has been followed at all, has "not been followed consistently. When the indicated result is absurd and is perceived to beso, there are means of escaping it." He then lists some of the means of escape. The place of contracting, he notes, "is not always intractable": it may be pos-

$$
{ }^{26} I d \text {. at } 246 . \quad{ }^{27} I d \text {. at } 242 . \quad{ }^{28} \mathrm{Id} \text {. at } 246 .
$$

${ }^{29}$ Compare 25 U. CHI. X. Rev. at 261-62, 267.

${ }^{30}$ Thus he tells us that because of the problem of service a suit against a Massachusetts married woman will have to be brought against her in her home state in the "overwhelming majority" of cases. 25 U. CHI. L. REV. at 247. On the other hand, he apparently assumes that in one-half of the cases a contract by a Massachusetts married woman will in fact be made outside Massachusetts, since "there is no a priori or other reason for supposing that more such contracts are made at home than abroad." Id. This may not be far from the mark; if a contract is deemed to have been made at the place where the offer was accepted, a married woman may find herself a party to an out-of-state contract without having left the statewhich indeed was the situation in Milliken v. Pratt. Id. at 235. Nevertheless, in the absence of empirical data - and none is presented by Professor Currie - there is of course no basis for an estimate concerning the actual incidence of various types of transactions.

31 25 U. CHI. L. REV. at 238.

${ }^{32} I d$. at $239-40,242$. 
sible, by "relocation," to obtain the desired change in the substantive law. Some of the bad results produced by the model could be avoided by the invocation of the forum's public policy, or of the rubric "fraud on the law." And we are told of the following "alternative" choice-of-law rules which are available in such a situation: "law of the place of performance, law intended by the parties, law giving validity to the contract, law of the place having the most substantial connection." ${ }^{33}$ Elsewhere, Professor Currie observes that most of the results he deems undesirable could be avoided by application of the rule, followed by some courts, that the capacity of a married woman to contract is governed by the law of her domicile. ${ }^{34}$

With these "devices" available, Professor Currie says that "an uninitiated reader might well ask whether any court would actually reach" the perverse results indicated in the six false-conflict cases. Proceeding to answer this question, he says "it may be doubted" that the judge who wrote the opinion in Milliken v. Pratt would have done so ${ }^{35} \mathrm{He}$ reveals that he is quite aware that judges have been known to resort to the same multiplicity of "devices" to achieve sensible results in the true-conflict cases as well as in the false-conflict cases. "A sensitive and ingenious court can detect an absurd result and avoid it; I am inclined to think that this has been done more often than not and that therein lies a major reason why the system has managed to survive."36

These are extraordinary concessions by one who would "scrap" 37 the existing system as hopeless. The system that he proffers as a substitute is concededly short of "ideal," 38 but assuming that it would yield generally good resultsaccepting for present purposes Professor Currie's views as to what is a good result-the "uninitiated reader" may well ask how the new system would fare at the hands of judges lacking in sensitivity and ingenuity.

The second of Professor Currie's case studies ${ }^{39}$ is based on the relatively recent case of Grant v. McAuliffe.$^{40}$ A California resident, driving in Arizona, hit a car occupied by three other California residents. The driver of the first car died as a result of the accident, and suit was brought against his Californiaappointed administrator, in California, by the three occupants of the second car. Under California law, a cause of action survives the death of the tortfeasor; under Arizona law it does not. The Restatement, ${ }^{41}$ with support in the cases, ${ }^{42}$ refers to the law of the place of the tort for the rule governing the survival of
${ }^{33} I d$. at $244-45$.
34 Id. at 254.
${ }^{35} \mathrm{Id}$. at 245.

${ }^{36} 1959$ DukE L.J. at 175. Cf. 10 StAN. L. REv. at 209-210; Purchase-Money Mortgages and State Lines: A Study in Contict-of-Laws Method, 1960 DuKe L.J. 1, 43 (with Mark S. Lieberman).
371959 Duke L.J. at 179.
${ }^{39} 10$ Stan. L. Rev. at 205.
3810 STAN. L. REV. at 245.
10 41 Cal.2d 859, 264 P.2d 944 (1953).
1 Restatement, Conflict of Laws $\$ 390$ (1934).
2 See 10 Stan. L. Rev. at 249-52. 
the cause of action. The California Supreme Court rejected the Restatement rule, and applied California law. Applauding the result, Professor Currie employs the case as a vehicle for the type of analysis he had made in the Milliken v. Pralt situation, based again upon fourteen hypothetical controversies with bi-state contacts. Once more the "cost" of the traditional rule is found to be "high," resulting in various "anomalies," including "frustration of California law and policy in four of the possible fourteen cases." 43

But here again Professor Currie is purportedly dealing only.with the product of a mathematical model rather than with the actual operation of the "system." Moreover, in his analysis of governmental interest he avowedly resorts to the use of "fiction" to avoid "excessively complex" 44 analysis-with the result that his tables would tell us little about actual "cost" even if they otherwise reflected the relative frequency of undesirable results. In any event, it is arguable that what he calls "fiction" is nothing more or less than resort to familiar choice-of-law rules which he believes advance the respective interests of California and Arizona more effectively in this instance than the Restatement rule. ${ }^{45}$ Finally, the curious fact emerges that, accepting Professor Currie's views

${ }^{43} I d$. at 235-36. See also p. 240.

${ }^{44} I d$. at 221.

45 Professor Currie believes that Arizona's adherence to the common law rule actio personalis moritur cum persona is probably due to inertia and therefore not representative of any "real policy." 10 STAN. L. REV. at 220 . He speaks of the probable origin of the rule at a time when the "penal conception of tort prevailed," ibid., and notes the obvious interest of the insurance lobby in keeping the rule alive. He concludes that the "most rational policy that can apparently be attributed to Arizona is that the living should not be mulcted for the wrongs of the dead: that the interests represented in the estate of the tortfeasor-his heirs, next of kin, devisees, legatees, creditors - should not suffer because of what he did.... The focal point of Arizona policy is the people who are interested in the estate of the deceased tortfeasor." Id. at 221. However, because such persons may be "numerous and scattered," Professor Currie states that for purposes of the analysis he proposes to undertake it "seems necessary ... to resort to fiction," ibid. Actually, he resorts to two fictions. He assumes that Arizona interests, based upon the existence of Arizona claimants, are involved if (1) the deceased tortfeasor was domiciled in Arizona; or (2) if the deceased tortfeasor left property in Arizona. His justification for the use of these particular assumptions is that the choice-of-law practice he so bitterly attacks has long recognized "both domicile and situs ... as relevant factors in determining the disposition of decedents' property." $I d$. at 222. Elsewhere he states that the assumed scope of Arizona policy "has been made as extensive as possible, for the academic purpose of strengthening the argument." $I d$. at 232.

Thus Professor Currie starts out with two fictions as a substitute for a presumed policy of Arizona which we are told is probably not its "real policy" anyway. On the basis of these fictions, he apparently believes that Grant v. McAuliffe should have gone the other way if brought in Arizona, against an ancillary administrator of the deceased California tortfeasor in an attempt to reach property of the decedent in that state; and he holds to this view even in a case where the accident, involving California residents exclusively, took place in California. 10 Stan. L. REv. at 226, 233-34. Yet the presence in Arizona of property of the deceased tortfeasor does not mean that the distributees and creditors of the California decedent are residents of Arizona; they are at least as likely to be residents of California.

It is interesting to observe what happens in these circumstances when suit is actually brought in California. All the four contact points employed in Professor Currie's analysis are now local: the domicile of the plaintiff; the domicile of the tortfeasor (the possible situs of the decedent's property in Arizona is ignored at this point by Professor Currie); the.place 
regarding governmental interest, and accepting also his statistical method; California fares better under the Restatement method than it does under Professor Currie's method-that is to say, the Restatement method yields results

of injury; and the forum. By the shift in the place of trial, a true-conflict case has been "transmuted," cf. id. at $245 \mathrm{n} .112$, into a no-conflict case. The possibility that the interests of the California plaintiff may be adverse to that of distributees and creditors actually residing in Arizona simply has no place in the analysis. In this instance the analytical method serves to conceal any actual conflict which may exist between specific interests of the two states.

The role of these fictions in Professor Currie's analysis is not entirely clear. If the facts are assumed to correspond to the particular fiction employed, then in a sense we do not have a fiction at all but a particularized hypothetical situation. Thus, it is possible to assume that a deceased California tortfeasor leaves property in Arizona and that all the claimants against his estate are Arizona residents with the solitary exception of the plaintiff, who is a California resident. One may then apply various choice-of-law methods to this hypothetical situation and compare the results. But the hypothetical situation is now so special and particularized that it is of limited value as a basis for conclusions as to the over-all "cost" of the rule that the law of the place of injury determines whether a cause of action survives the death of the tortfeasor.

As indicated in the text, however, the resort to "fiction" can perhaps be better explained in another way. It is arguable that, while inveighing against formal choice-of-law rules in very strong terms, Professor Currie has measured Arizona's interest by two formal choice-of-law rules in place of the particular rule indicated by the Restatement in such a case; in this light the "fiction" may be seen as the assumption that Arizona's interests are in fact furthered by these rules without regard to the actual facts. If this is the analytical method employed by Professor Currie, he has chosen peculiar means to demonstrate the inherent unworkability of formal choice-of-law rules.

That this is in fact his analytical method is borne out by his approach to the problem of California's interest in a case where California's only contact with the controversy is as the place where the accident occurred and as the forum - the parties to the suit being, on the one hand, an Arizona plaintiff, and, on the other, the ancillary administrator of a deceased Arizona tortfeasor. The result which Professor Currie indicates to be the desirable one is that the California court should apply California law regarding survival of the cause of action. His supporting argument is essentially as follows: when a person is injured in California, it is possible that public or private agencies within the state may incur expense in treating him; California has an interest in permitting suit by such agencies, notwithstanding the non-survival rule of the deceased tortfeasor's domicile; certain Supreme Court cases (as construed by Professor Currie) permit California to apply its internal rule whether or not the estate of the tortfeasor is actually subject to claims by such local agencies; therefore, California should apply its local rule in the suit by an Arizona plaintiff whose interest is of no concern to California, id. at 221,225, which is tantamount to saying that California should assume a local interest to be involved though none in fact exists. Again, it would seem that a formal choice-of-law rule is being employed. And Professor Currie is seemingly undisturbed by the prospect that the rule he puts forth may thwart an assumed Arizona interest without any discernible benefit to California. It is enough for him that the Supreme Court "has declined to be so particularistic as to inquire whether the injured person actually became a burden to the state where the injury occurred." Id. at 221 n.64. From the fact that a "conventionalized" basis for discerning the interest of the state may be employed without risking reversal by the Supreme Court, $c f .26$ U. CrI. L. REv. at 23 , it does not follow that this is necessarily the basis to be employed in a critical study of the methods by which governmental interest may be rationally advanced. In a later article Professor Currie clearly recognizes that the assumed policy of California which he has thus used as a device for measuring the social utility of alternative methods of choice of law is a policy which presses "to the outermost limits of reasonableness." Currie, The Silver Oar and All That: $A$ Shidy of the Romero Case, 27 U. CHI. L. REv. 1, 67-68 (1959).

Although he has classified judicial results as desirable or undesirable on the basis of whether 
favorable to California in a higher number of possible cases. ${ }^{46}$ Professor Currie recognizes this, and his explanation is that "California policy suffers because Arizona law is different." 47 But California policy would not suffer, despite this difference, if both states adhered to the Restatement rule. If, as Professor Currie believes, the value of a choice-of-law method is to be measured by the consistency with which it advances governmental interest, it would seem that, in this instance at least, he has chosen an unfortunate example to illustrate the costs of the traditional method.

The two case studies which have thus far been described constitute the foundation ${ }^{48}$ of his attack upon what he calls the "taught system of choice of law." 49 It is important to ascertain what he means by this "system" and what he be-

\section{[footnote 45 continued from preceding page]}

they accord with the assumptions regarding local interest which have heretofore been discussed it is possible to view his article as being intended only to suggest how Arizona and California could rationally go about effectuating their local interests, and not as intended to suggest any particular formula for doing so. The fact remains, however, that he seems to have done no more than to compare the results produced in certain hypothetical cases by alternative choiceof-law rules.

4610 Stan. L. REv. at $244 \mathrm{n}$.109. This takes into account the sum of the results in the courts of both states. Each of the states would of course do better in its own courts, assuming that Professor Currie's assumptions as to the interests of the respective states are sound. See note 45 supra.

47 Ibid.

${ }^{48}$ Of the nine articles by Professor Currie cited in note 1 supra, these two case studies appeared first in point of time. Since the entire series was published within a two-year period, the order in which the articles appeared is not necessarily indicative of the order in which the ideas expressed in them took shape. The fact remains that in the first two articles the traditional system of choice of law is condemned without reservation, and the essentials of Professor Currie's proposal for replacing it are fully set forth. Hence it is not unreasonable to suppose that the presentation made in these two articles was deemed adequate by the author to support his vigorous conclusions and recommendations.

In fact, some of his subsequent articles have also taken the form of case studies. The present writer is informed that the penultimate article in the series cited, Purchase-Money Mortgages and State Lines-A Study in Conflict-of-Laws Method, 1960 DUKE L.J. 1 (with Mark S. Lieberman), was in fact conceived before any of the others although its execution was postponed. This article is in form a case study, but the method employed is not the exhaustive analysis of hypothetical possibilities which characterized the first two case studies. The emphasis is on the nature of the particular state policy involved and on effective means for implementing it. Much of the analysis appears to be unexceptionable, but even less is shown than in the first two case studies to support the conclusions that the old "system" is inherently unworkable. Another case study is to be found in The Silver Oar and All That: A Shudy of the Romero Case 27 U. CEI. L. REv. 1 (1959), but the case on which the analysis centers was decided subsequent to publication of the first two articles; while primarily concerned with admiralty matters, this case study also deals in part with choice of law, $i d$. at 65-75, but again the analysis is particularized and seems insufficient to afford a basis for a general condemnation of the "system." The third of the articles in point of time, The Constitution and the Choice of Law: Governmental Interests and the Judicial Function, 26 U. CEL. I. REV. 9 (1958), tends to refute rather than to confirm Professor Currie's position, as is indicated in note 97 mfra. The remaining articles deal for the most part with problems raised by his suggested approach to choice of law, and contain little that is relevant to a general appraisal of more traditional approaches.

1910 STAN. L. Rev, at 241. 
lieves he has demonstrated about its shortcomings. Initially it may be noted that he does not attack the results actually reached by the courts in the two cases which are the starting-points of his analysis; he expressly supports the result in Grant v. McAuliffe and does not indicate disagreement with the result in Milliken v. Pratt. The attack is centered upon two relatively narrow choiceof-law rules which, in the range of possible controversies in which they might be applied, are alleged to yield irrational results in terms of the effectuation of relevant governmental policies. These rules happen to be embodied in the Restatement of the Law of Conflict of Lares, and would undoubtedly be followed by some courts in circumstances where to do so would be undesirable.

Professor Currie's conclusion from this seems really to be no more than an assumption-the assumption that what has been produced is a demonstration of how formal choice-of-law rules characteristically operate. The assumption is that relevant governmental policies are, of necessity, advanced only haphazardly as long as the solution of choice-of-law problems is sought in conventions or rules which refer to the law of a particular place deemed to have a connection of special significance with the matter in controversy. The "taught system" which is condemned is sometimes seen as the system associated with the late Professor Beale, ${ }^{50}$ but it is clear that the target is broader-it is the more or less universal tendency, which has characterized the development of the law of conflict of laws from its beginnings in the late Middle Ages, to achieve localization, through conventions or rules, of the legal consequences of transactions having connections with more than one place. ${ }^{51}$ When Professor Currie charges that the "taught system" is "wretched and spurious"52 - a "mindless and ruthless machine" spewing "innane automatisms" it is the broader target at which his attack is directed.

For the present it is perhaps sufficient to note again (1) that Professor Currie's purported demonstration really tells us nothing about the actual cost of the "system" in terms of the relative frequency of undesirable results; (2) his remarkable concession that for all its faults the "system" works tolerably well when it is administered by "sensitive and ingenious" judges; and (3) the fact that he would replace it with a very different kind of system without any consideration whatever of how the new system would fare at the hands of judges who are something less than sensitive and ingenious. Attention will now be directed to this new system.

\section{The Proposal to Abolish Chotce-of-Law Rules and to SUBSTITUTE THE RULE OF GOVERNMENTAL INTEREST}

As indicated earlier, Professor Currie has written that "we would be better off without choice-of-law rules." ${ }^{34}$ But he does not propose that foreign law

so See, e.g., 10 STan. L. REv. at 209.

51 See note 95 infra.

${ }^{53}$ Id. at 237.

s2 10 STAN. L. REv, at 241.

54 See note 4 supra. 
should never be applied; under his system a court would still be faced with the problem of choosing between local and foreign law, or possibly between the law of two or more foreign jurisdictions. Thus he is not so much proposing the abolition of choice-of-law rules as proposing that the traditional rules be abandoned in favor of a different approach to the problem.

At the outset it should be noted that Professor Currie does not purport to have originated the theory that choice-of-law rules should rationally advance the policies or interests of the several states (or of the nations in the world community). Leaving aside for the moment the question of when this theory was first advanced, the fact is that scholarly criticism of the law of conflict of laws during the last four decades has elaborated the theory with such great success that today it is largely taken as axiomatic by scholars, if not always by judges. ${ }^{55}$ As has been seen," Professor Currie believes that governmental interests cannot rationally be effectuated by a formalized system of rules for choice of law-a view which presumably is not shared by those who are laboring on the Second Restatement of the Law of Conflict of Laws. He has a high regard for certain modern writers to whom he attributes proposals for dealing with choice of law which are essentially ad hoc in character, or, as he puts it, "formfree." ${ }^{\text {" }}$ He states that the work of these writers represents "the finest fruits of critical attempts to deal with the problem," ${ }^{57}$ but he believes that all such previous attempts have failed. As he sees it, the aim of the writers of the "formfree" school has been to provide methods for the "solution" of conflict problems, either by "weighing" the competing interests of the several states involved and selecting the governing rule on that basis, or by deliberately seeking the just result in the particular case, which may also involve the appraisal of governmental interest, since justice as between the immediate litigants is commonly seen by such critics in terms of the application of truly relevant governmental policies. Professor Currie believes that these are not proper judical functions.

Under his own system a court would eschew such interest-weighing, and apparently it would eschew any attempt to reach a just result as such. As noted before, the court would simply advance the interests of the forum state if any are in issue; if domestic interests are not in issue, the court would effectuate the foreign interests which are at stake in the litigation. Professor Currie concedes that this approach is not ideal, stating that in some areas it is desirable, in the interest of uniformity, to have rules "which, on a rational basis, require the policy of one state to yield to that of another...."

${ }^{55}$ See the numerous authorities collected in Kramer, Interests and Policy Clashes in Confict of Laws, 13 RuTgers I. Rev. 523, $533 \mathrm{nn}$. 26-38 (1959). Many of these authorities are cited in notes 126, 127 infra.

${ }^{56} 25$ U. ChI. L. REv. at 249.

${ }^{57}$ Ibid.

${ }^{58} \mathrm{Id}$. at 267. See also id. at 262; 26 U. CHr. L. Rev. at 82, 84; 10 STAN. L. REv. at 245; 1959 DUKE L.J. at 181. 
lieves, should be promulgated by legislative authority-specifically Congressand not by the courts. ${ }^{59}$ His reasons are essentially as follows:

[W]here several states have different policies, and also legitimate interests in the application of their policies, a court is in no position to "weigh" the competing interests, or evaluate their relative merits, and choose between them accordingly.... [w] [wen the court, in a true conflict situation, holds the foreign law applicable, it is assuming a great deal: it is holding the policy, or interest, of its own state inferior and preferring the policy or interest of the foreign state. ... [t]he task is not one to be performed by a court. I know that courts make law, and that in the process they "weigh conflicting interests" and draw upon all sorts of "norms" to inform and justify their action.... But assessment of the respective values of the competing legitimate interests of two sovereign states, in order to determine which is to prevail, is a political function of a very high order. This is a function which should not be committed to courts in a democracy. It is a function which the courts cannot perform effectively, for they lack the necessary resources. Not even a very ponderous Brandeis brief could marshall the relevant considerations in choosing, for example, between the interest of the state of employment and that of the state of injury in matters concerning workmen's compensation. This is a job for a legislative committee, and determining the policy to be formulated on the basis of the information assembled is a job for a competent legislative body. ${ }^{60}$

Boiled down, the reasons are two: (1) The courts are not qualified to perform the task. (2) In any event, it is undemocratic for the courts to assume the task.

As far as the first reason is concerned, some scholars believe that the courts are better qualified to perform the task than the legislatures. ${ }^{61}$ Professor Currie himself characterizes as "appalling"62 and "footless" 63 some of the legislative proposals and measures which have heretofore come forth, and has "grave misgivings $"$ "64 about what will be forthcoming in the future. But even assuming a lesser competence in the courts, it is not clear why they must engage in "the pursuit of self-interest," 65 regardless of consequences, pending legislative reform. If, to employ his own terms, it is desirable in some areas that the policy of one state should yield to that of another, and if, as he seems to believe, a rational approach to this problem by the courts is not impossible, it is not clear

${ }^{69}$ Because he believes that the basic problem of the conflict of laws is to reconcile or resolve the conflicting interests of different states, Professor Currie concludes that a state legislature is really in no better position to take effective unilateral action than is a state court, though he thinks the legislature could be of assistance in at least making it clear just what the local policy is. 10 Stan. L. Rev. at 246-48; 25 U. CHI. L. REv. at 259. He sees a possibility of some legislative progress in interstate compacts, but thinks federal legislation would be more effective. See 25 U. CHI. L. REv. at 263-68.

${ }^{60} 1959$ DUKE L.J. at 176-77.

${ }^{61}$ E.g., Traynor, Is This Confflct Really Necessary?, 37 Texas L. Rev. 657, 675 (1959), Cf. 10 STAN. L. REv. at 246.

6226 U. CHI. L. Rev. at 84 n.334.

${ }^{63}$ Id. at 19.
${ }^{64}$ I $\dot{d}$. at $84 \mathrm{n} .334$.

${ }^{65} \mathrm{Id}$. at 11. 
why the courts must desist from all efforts in this direction. Thus, standing alone, the first reason seems insubstantial.

The second reason, in Professor Currie's own language, is that "this is a function which should not be committed to courts in a democracy." The meaning is not readily apparent. Since the work of the state courts, with which he is principally concerned, is in the great majority of states discharged by elected officials, ${ }^{66}$ the exercise of governmental power in this instance is not undemocratic in the sense that it is removed from popular control. What Professor Currie seems to mean is that the "function" of which he speaks may not appropriately be vested in the judiciary in light of the distinctively (but not uniquely) American principle of separation of powers. The fact is, of course, that the great bulk of our law is judge-made law, and that in the development of such law some interests are affected favorably and others adversely; this much Professor Currie accepts. It is when a balance is to be struck between domestic and foreign interests (adopting for the present his statement of the issue) that he draws the line; this is a "political function of a very high order," to be discharged only by a legislature. It is difficult to deal with such an argument, which is essentially a judgment as to the proper distribution of power in our society, and not susceptible of being proved or disproved. It is permissible to inquire, however, into how firmly Professor Currie himself believes in this argument.

In this connection it may be observed initially that Professor Currie does not take the position that the forum should engage in the ruthless pursuit of selfinterest in the sense that every conflict case should be decided in favor of local residents to the extent that the Constitution permits. When he says that a court should promote the governmental interests of the forum he means that it should effectuate local governmental policies which are essentially indigenous-which represent primarily a regulation of the internal affairs of the forum. In one of his hypothetical cases a married woman who resides in Maine (under whose law married women may freely contract) makes a contract in Massachusetts (a contractual incapacity state) with a Massachusetts creditor, who thereafter sues her on the contract in Maine. Under the place-of-contracting rule the Maine woman would have a perfect defense, but Professor Currie would reject the place-of-making rule in favor of one by which each state is enabled consistently and rationally to advance its own interests. Should Maine, having rejected the place-of-making rule, find some means of shielding its married woman in this instance? Professor Currie considers various alternatives, and notes the constitutional problems which arise. He concludes, however, that even if there were no constitutional obstacles, Maine should not endeavor to create a defense for its married woman - that in this instance the foreign interest should be preferred to the local interest. ${ }^{67}$ Maine does not really have a policy of protect-

${ }^{66}$ See Trumbull, The State Court Systems, ANn. AMr. Ac. Pol. \& Soc. Sc., March, 1960, pp. 134, 140-141.

${ }^{67} 25$ U. CHI. L. Rev. at 257-58. 
ing its married women from their contractual indiscretions; it would not afford such protection to a Maine married woman in a controversy with a Maine creditor, and it should not do so in a controversy with a Massachusetts creditor. Professor Currie is not sympathetic to rules designed "to discriminate against as many foreigners as possible." ${ }^{68} \mathrm{He}$ repeatedly counsels that the pursuit of self-interest should be practiced with "moderation,"69 by which he means (1) that local interests should not be deemed to be involved unless relevant governmental policies of an indigenous character are involved; and (2) that a court should proceed with caution when it is asked to find that a conflict exists between local policies and those of another jurisdiction.

Quite apart from the merits of this counsel of moderation, one cannot but be struck by the breadth of the power that Professor Currie says the judiciary may properly assume. Cases are systematically to be decided against local residents in situations where the Constitution would permit a contrary result. In Professor Currie's lexicon this would seem to represent a "political" decision of a "very high order." Apparently the power to make important political decisions is to be accorded to the judiciary despite the principle of separation of powers.

This becomes particularly evident when it is noted that Professor Currie suggests that a court may properly engage in acts of "rational altruism."70 By way of illustration he states that "when a state has determined upon the policy of placing upon local industry all the social costs of the enterprise, it may well decide to adhere to this policy regardless of where the harm occurs and who the victim is." "71 Judging from the case to which he refers at this point, ${ }^{72}$ it appears that what Professor Currie has in mind is that a local rule of strict liability, which does not brook the delegation of a duty of care, may properly be made available to an out-of-state accident victim even though the local resident being sued would not be liable under the law of the place where the injury occurred. Again it would seem that a significant political function is being assigned to the judiciary.

Professor Currie's hostility to judicial interest-weighing has led him to a strange result so far as the disinterested third state is concerned. To illustrate the point we may again use his assumed controversy between a Massachusetts married woman and a Maine creditor. This case represents to him a true

${ }^{68} I d$. at 258.

${ }^{69}$ See, e.g., 25 U. CHI. L. Rev. at 256, 258; 26 U. CH. L. Rev. at 11, 83; 1959 DukE L.J at $179-80$.

701959 DUKE L.J. at 180.

71 Ibid.

72 Professor Currie invites the reader to compare the case of Schmidt v. Driscoll Hotel, 249 Minn. 376, 82 N.W.2d 365 (1957), in which the Minnesota Supreme Court held the liability provisions of that state's dram shop act available to a person who had received his injury outside the state. 
conflict of interests, which should be resolved by a Massachusetts court in favor of the Massachusetts interest and by a Maine court in favor of the Maine interest. ${ }^{73}$ But what if the Maine creditor sues the Massachusetts married woman in New York? Professor Currie has abolished choice-of-law rules; he has substituted rules telling Massachusetts and Maine, as interested states, what to do; he has neglected, however, to make provision in his system as to what New York is to do in such a case.

He suggests that in such a situation New York might apply its own law, ${ }^{74}$ or "the foreign law that coincides with its own ...," has no enthusiasm for such approaches, which make the outcome depend upon the policy of a state having no connection with the operative facts of the controversy. ${ }^{76}$ Besides, the law of the forum might be quite different from that of the several interested jurisdictions, and Professor Currie is aware that it would not be constitutionally permissible to apply the law of the forum in such a case. ${ }^{77}$ Alternatively, he suggests that "a broadened doctrine of forum non conveniens would provide a handy solution for [New York's] difficulty," he recognizes that there are constitutional obstacles to such a "solution" as well, and gives some consideration to its social costs. ${ }^{79}$ His basic position seems to be that New York is in "a quite impossible position in the absence of Congressional guidance." $\$ 0$ Now obviously New York is not going to receive such Con-

${ }^{73} 25$ U. CHI. L. REV. at 262.

. ${ }^{74}$ Cf. On Displacement of the Law of the Forum, 58 CoLur. L. Rev. 964, 1015-18 (1958).

${ }^{75} 25$ U. Crr. L. Rev. at 262.

76 Ibid.

${ }^{77} 26$ U. CEn. L. Rev. 9 (passim).

7825 U." Crr. L. Rev. at 262 n.64.

${ }^{70}$ Currie, The Constinution and the "Transitory" Canse of Action, 73 HaRv. L. REv. 36 (Part I), 268 (Part II), at 274-83 (1959); Currie, On Displacement of the Law of the Forum, 58 Coluss. L. Rev. 964, 1015-17 (1958).

The defendant may not be amenable to suit in any other state, having removed both his person and his property to the third state. It may be argued that the third state is now no longer disinterested, and that it may freely assert the local interest created by this change of circumstances, but in many situations this would not be constitutionally feasible, see $\mathrm{p}$. 484 infra, to say nothing of the general undesirability of such a practice. Moreover, Professor Currie's system is hostile to the assertion of interests which are not contemporaneous with the operative facts of a particular controversy, although this does not stop him from speculating about the application of the lex fori on grounds of alleged necessity.

It may be argued, too, that in such a case it may be possible, by one device or another, to compel the parties to litigate in a state which does have (or which used to have) a legitimate interest, of. Griswold, Renvoi Revisited, 51 HaRv. L. REv. 1165, 1189 (1938), but this may involve undue hardship for one or both of the parties, and the social cost may well be excessive when it is considered that the only gain is that the courts of the forum are spared the task of resolving onerous choice-of-law problems; the same considerations may be applicable even when in a technical sense the defendant was all along amenable to service in an "interested" jurișdiction.

${ }^{80} 26$ U. CHI. L. Rev. at 82 n.326. 
gressional guidance, which to be adequate would have to take the form of a complete statutory system of choice of law. If New York's position is "impossible" it is because Professor Currie's theory simply makes no provision for the treatment of a significant class of cases-significant particularly in a federation like the United States.

What of the role of the interested forum? Thus far, no question has been raised concerning the validity of Professor Currie's underlying premise-that in the typical choice-of-law situation the court is dealing essentially with an interstate conflict. He sees the function assigned to the courts by all previous theories of the conflict of laws as the making of a choice between the interests of the one state or of the other-either on the basis of formal rules which are not rationally addressed to the problem of governmental interest, or on the basis of $a d$ hoc methods of interest-weighing and the like which are not necessarily irrational but which he believes the courts should not adopt for reasons already discussed. The assumption is that the courts have traditionally been assigned the function of resolving the controversy in accordance with the dictates of a particular theory or method even if the domestic interest is disadvantaged by the result. The proposal to abolish choice-of-law rules is essentially a proposal to abolish this function. It is submitted that Professor Currie has taken an unduly narrow view of the function of the courts in conflict cases, and that his analysis suffers accordingly.

What he has largely overlooked is the extent to which the development of a choice-of-law rule is the outcome of a clash of competing interests of an intrastate character. In theory, as Professor Currie puts it, a state could "maximize"s1 its interests by deciding every controversy in favor of the local residents involved. But the pursuit of self-interest in this fashion would mean systematic discrimination against citizens of other states, which the Constitution forbids ${ }^{82}$ and which Professor Currie would deplore on any account, as has already been seen. In some situations the local resident must lose, and there must be rules for determining, with a reasonable degree of consistency, when he will win and when he will lose. How should these rules be developed?

Consider the problem of a Massachusetts court in a suit between a Massachusetts creditor and an out-of-state married woman on an out-of-state contract. Let it be assumed, as in Professor Currie's example, that, with a view to protecting its married women, Massachusetts adheres to the common law rule which permits a married woman to avoid her contracts. Professor Currie contends that Massachusetts can do without choice-of-law rules-that it should simply effectuate local policies when substantial local contacts bring

8125 U. CHI. L. Rev. at 237.

22 Such discrimination against the citizens of other states is forbidden by the privileges and immunities clause of art. IV, $\delta 2$, and, in certain situations, by the equal protection clause of the fourteenth amendment, $\$ 1$. 
these into play. The local policy for the protection of married women ${ }^{83}$ is irrelevant in the case of an out-of-state married woman. The only local policy that is relevant is the policy which favors the security of commercial transactions entered into by local residents, and this policy should be effectuated; that is to say, the local creditor should prevail. In Professor Currie's view, the law of the place where the contract was made should be deemed immaterial in such a case.

Let it be assumed, however, that the married woman is a citizen of state $\mathrm{X}$ which, like Massachusetts, adheres to the common law rule concerning married women's contracts. Professor Currie recognizes that if Massachusetts accords the protection of this rule to its own married women irrespective of the place where the contract was made, it must accord the same benefit to an out-of-state married woman who, as here, receives similar protection under the law of her domicile. ${ }^{84}$ Thus there emerges from Professor Currie's deliberations the not unfamiliar choice-of-law rule which looks to the place of domicile for the law governing capacity to contract. ${ }^{85}$ Professor Currie does not believe that this rule should be adopted generally, but he does think it to be an appropriate rule for a state which itself retains the common law approach to married women's contracts. ${ }^{86}$

To carry the problem to a stage not considered by Professor Currie, let it be assumed further that the contract in this case was made in state $Y$, where a married woman may freely contract. If Massachusetts is committed to the rule that the law of the married woman's domicile governs, its resident creditor in this case will lose, as will all resident creditors similarly situated. However there is a way to permit such a creditor to prevail. If Massachusetts adopts the rule, not just for this case, but generally, that the law of the place of making is determinative on the issue of capacity, this resident creditor will win, as will all others of his class. But other resident creditors will suffer: e.g., one who brings suit in Massachusetts, on a contract made in that state, against a married woman who has contractual capacity under the law of her domicile. The peculiar impact of each of these alternative choice-of-law rules on Massachusetts married women is also to be considered. When that has been done, the relative interests or claims of the two classes of local residents may still have to be settled. Is a relatively minor advantage for local married women to be sought at the expense of a relatively major disadvantage for local creditors? Questions of this sort can easily be multiplied.

Thus the constitutional requirement that choice-of-law rules be non-discriminatory - that they be applied with a reasonable degree of consistency-

${ }^{83}$ See note 22 supra.

84 25 U. CHr. L. Rev. at 255-58. Cf. 10 STAN. L. Rev. at 231-32. Quaere, whether this is necessarily true if state $X$ itself follows the place-of-making rule?

${ }^{85}$ See Stumberg, Conelict of Laws 241 (2d ed. 1951).

${ }^{8 B} 25$ U. ChI. L. Rev. at 256, 261. 
means that a rule which favors one group of residents today will have to be followed even if it disfavors another group of residents tomorrow. This is the problem that confronts a court when it considers for the first time the adoption of a particular choice-of-law rule, either as a matter of first impression or as a contemplated clean break with the choice-of-law practice of the past. That the courts only occasionally articulate their concern with this problem ${ }^{87}$ does not mean they are oblivious to it the rest of the time. Certainly a realistic appraisal of governmental interest is the very thing Professor Currie would have them undertake. But, as has been seen, the problem is not the simple one of advancing governmental interest vel non. For governmental interest is a bundle of diverse and sometimes conflicting interests. To the extent that the legislature leaves unresolved the problem of choice among these interests, the courts have no alternative but to make the choice themselves. ${ }^{88}$ And, as will be noted below, there may be sound reasons why the courts should assume this burden quite apart from any constitutional compulsion on them to do so.

To recapitulate: a controversy in which a particular domestic interest is pitted against a particular foreign interest has, by hypothesis, its interstate (or international) aspect, but, for reasons which have been indicated, this is not its exclusive aspect. A victory for the domestic interest immediately at stake in the litigation may be foregone because such a result would be deemed detrimental to other domestic interests, including, it may be noted, interests which are general in character, such as the interest in uniformity of outcome in certain types of situations, or the interest in a legal order which operates to the mutual convenience of the respective states.

Thus, the resolution of the controversy in favor of the foreign interest immediately involved may, in another of its aspects, be viewed as the resolution of an intrastate controversy in favor of one or more domestic interests deemed weightier than the domestic interest immediately at stake in the litigation. If a sufficiently broad view is taken of governmental interest, it may be that resolution of the intrastate conflict is the only issue with which the court should properly concern itself; in other words, that the court should consider only the interests of the forum. Indeed, if a sufficiently broad view is taken of governmental interest, it may be that by and large this is what the courts are doing.

\section{The Problens of Governatental INTEREST CONSDERRed FuRTHER}

It has been noted earlier that it is now taken as axiomatic, at least by scholars, that choice-of-law rules should rationally advance the policies or interests of the several states (or of the nations in the world community). ${ }^{89}$ The fact

${ }^{87}$ E.g., Lams v. F. H. Smith Co., 36 Del. 477, 178 Atl. 651 (1935).

${ }^{88}$ Compare the treatment of this problem in Kramer, Inlerests and Policy Clashes in Conflict of Laws, 13 RUTGERS L. REv. 523 (1959).

${ }^{89}$ See note 55 supra. 
is that the concern with governmental interest is also apparent in the writings of the earliest formulators of the territoriality principle in the law of conflict of laws. As Huber put it, "nothing could be more inconvenient to commerce and to international usage than that transactions valid by the law of one place should be rendered of no effect elsewhere on account of a difference in the law." 90 Huber further said:

$\therefore$ It is not by reason of the immediate force and operation of a foreign law, but in consequence of the sanction of the supreme power of the other state, that effect is given to foreign laws exercised upon property within its territory, out of respect for the mutual convenience of the nations, provided, however, that no prejudice is occasioned to a sovereignty or to the rights of its citizens, which is the foundation of the :whole subject. [Emphasis supplied.] ]1

Since the prejudice to be avoided is prejudice which might be occasioned by the application of the foreign law, Huber seems to be stating unmistakably that the basic objective of the law of conflict of laws is to advance the governmental interests of the forum. Essentially similar views were expressed by Justice Story, who took Huber as his model in writing his epochal treatise. ${ }^{92}$ Nor should this be surprising. The comity theory, which served both Huber and Story, has really no place for foreign law except upon the basis of mutual convenience. If the vested rights theory of the conflict of laws has proceeded upon different premises, ${ }^{93}$. the fact remains that the vested rights theory produced few truly fundamental changes in the structure of choice-of-law principles with which the early territorialists are identified.

It is not intended to suggest that this structure was deliberately fashioned by the territorialists on the basis of preconceptions as to the function of choiceof-law rules. Huber's rules were not deduced from the famous Three Canons which embody the fundamentals of his conception of territoriality. What Huber did was to codify the conflict-of-laws practice followed in his time in the newly-independent states of the Netherlands; the Three Canons (and their corollary in the theory of comity) were essentially rationalizations of that practice. ${ }^{94}$ Other scholars and jurists have rationalized in other ways the locali-

${ }^{90} \mathrm{De}$ Conflich Legum Diversarum in Diversis Imperiis, as translated by Professor Lorenzen iñ an appendix to his article entitled Huber's De Conflichu Legum, 13 ILI. L. REV. 375, 401 (1919). The article, including the appendix, is reprinted in LoRENzen, SELECTED ARTICLES ON THE CONFIICT OF Laws 136, 162 (1947). The language quoted in the text appears at 13 Irt. L. Rev. 403; Lorenzen, Selected Articles on the Confrict of Laws 165.

91 13 ILI. L. Rev. at 412, Lorenzen, Selected ARticles oN the Conflict of Laws $173-74$.

92 Story; ComanentaRy oN THe Conflict of LAws 24-38 (1st ed. 1834). Cf. Katzenbach, Conflicts on an Unruly Horse: Reciprocal Claims and Tolerances in Interstate and International Law, 65 YaLE L.J. 1087, 1102-06, 1119 (1956).

- 93.See Cheatham, American Theories of Conflict of Laws: Their Role and Utility, 58 Harv.

L. REv. 361 (1945).

94 See LORENZEN, op. cit. supra note 90. 
zation of the legal rules governing transactions having contacts with more than one place. One cannot but be struck by the universality of the impulse to achieve localization since the beginning of the modern law of conflict of laws in the late Middle Ages, and by the recurrence of certain general patterns of localization: e.g., place of making or performance in cases of contract, place of residence or domicile, situs of immovables..$^{95}$ Professor Currie seems to assume that the traditional choice-of-law rules represent the product of "metaphysical" speculations "concerning the nature of law and its abstract operation in space." What is more plausible is that the rules represent, in the main, rational responses to the felt necessities of the times in which they were produced; that writers from the time of Bartolus to the time of Beale have taught us much about the nature of governmental interest and the means for implementing it; and that the system traditionally employed in the United States embodies much of these teachings. ${ }^{97}$

${ }^{95}$ See 3 Beale, Conflict of Laws 1880-1975 (1935); Cheshure, Prvate International LAW 22-57 (3d ed. 1947); LoRENzEN, op. cii. supra note 90; Lorenzen, Story's Commentaries on the Conflict of Laws-One Hundred Years A fler, 48 HARv. L. REv. 15 (1934), appearing also in Lorenzen, Selected ARtictes on the Conflict of Laws 181 (1947); Yntema, The Historic Bases of Privale International Law, 2 Asr. J. OF Cosp. Law 297 (1953); Ehrenzweig, American Conflicts Law in its Historical Perspective: Should the Restatement be "Continued"?, 103 U. PA. L. REv. 133 (1954); Nadelmann, Some Historical Notes on the Doctrinal Sources of American Conticls Law, in IUS Ex LEX, FESTGABE Für MAX GUTzwitler 263 (1959). Cf. Ehrenzweig, The Lex Fori in the Conflict of Laws-Exception or Rule?, 32 Rockx MIT. L. REv. 13, 16-18 (1959); Ehrenzweig, The Lex Fori-Basic Rule in the Conflict of Laws, 58 MicH. L. REv. 637 (1960). Professor Ehrenzweig sees a significant place for "traditional conflict rules as exceptions to a basic law of the forum"; far from being opposed to such rules, he would "promote the actual application of foreign law by improving and refining the rules pertaining to specific typical situations." Id. at 642 .

${ }^{36} 1959$ DUKE L.J. at 173-74. Professor Currie's meaning is not entirely plain, for he tells us also that judges dealing with conflict problems "will not be so bold (or so frank) as to avow that they are assuming the high political function of passing upon the relative merits of the conflicting policies, or interests, of sovereign states." Id. at 173. Possibly he means that the "metaphysical" speculations are only a facade behind which the "high political function" he speaks of is willingly and deliberately discharged. If so, he is harsh indeed in his conclusión that centuries of conscious effort along these lines have produced nothing better than a "mindless and ruthless machine" which spews "inane automatisms." 10 STAN. L. Rev. at 237. See also id. at 240-41, 247-48. However, the general impression conveyed by Professor Currie's writings is that he believes judges and until recently scholars have been oblivious to the proper function of a court in a conflict situation, and that they have been beguiled by "metaphysical" preoccupations into producing the "interest-wrecking mechanics of the system." Id. at 248. Cf. Currie, Change of Veme and the Conflict of Laws: A Retraction, $27 \mathrm{U}$. CirI. L. Rev. 341, 343 (1960).

${ }^{97} \mathrm{Cf}$. Lorenzen, Territoriality, Public Policy and the Confict of Laws, 33 YaLe L.J. 736, 748-51 (1924), reprinted in LORENZEN, SELECTEd ARTiCles oN THE Conflict of LAwS 1, 14-18 (1947); Neuner, Policy Considerations in the Conflict of Laws, 20 CAN. B. REv. 479, 480 (1942).

Some confirmation of this point was indirectly furnished by Professor Currie himself in his study of the choice-of-law cases decided by the Supreme Court under the full faith and credit clause and the due process clause. $26 \mathrm{U}$. CHr. L. REv. 9 (1958). In this article he observed that since its decision in Alaska Packers Association v. Industrial Accident Commission, 294 U.S. 532 (1935), the Supreme Court has deliberately and consciously analyzed such problems 
As a matter of fact, Professor Currie himself is not insensitive to these teachings. He tells us that the rational pursuit of domestic interest is the only proper function of a court in a conflict situation, and he tells us further that in the last analysis the interest of a state is in its people. From this it would seem to follow that the domestic interest is advanced every time a controversy is resolved in favor of a local resident. As has been seen, Professor Currie does not believe the courts should go this far. Why not? Consider this basic problem: $A$ and $B$, as residents of state $X$, make a contract in state $X$, which by its terms is to be performed in state $\mathrm{X}$; thereafter $\mathrm{A}$ becomes a resident of state $\mathrm{Y}$, and litigation concerning the contract takes place in a court of state $\mathrm{Y}$. May the court apply the internal law of $\mathrm{Y}$ to favor the party who is now a resident of that state? The Supreme Court has said that it may not, ${ }^{98}$ and Professor Currie, who does not hesitate to criticize the Supreme Court when he believes it to be wrong, states that in this instance it is right. ${ }^{99}$ And his explanation amounts to little more than an assertion that the very real interest of state $\mathrm{Y}$ in such a situation is not a "legitimate interest." 100 It is for this reason that he believes the assertion of such an interest would be in contravention of the due process clause ${ }^{101}$ and the full faith and credit clause; ${ }^{102}$ and it is apparent that he looks with disfavor upon the assertion of such an interest quite apart from the fact that the Constitution forbids it in any event.

So, too, it is apparent that his view, previously alluded to, that a state should not adopt rules designed "to discriminate against as many foreigners as possible," 103 rests upon considerations independent of the privileges and immunities clause ${ }^{104}$ and the equal protection clause. ${ }^{105} \mathrm{He}$ would favor local residents (but not all local residents) only insofar as this would be the consequence of effectuating domestic policies which are truly indigenous in the sense that they have their

in terms of governmental interest, as compared with earlier cases in which the Court had leaned to "territorialist dogma." $26 \mathrm{U}$. CHr. L. REv. at 48. Yet even among these earlier cases he found a high proportion which were properly decided in light of his own analysis based upon governmental interest. Apparently this finding has not altered his conviction that the methods of choice of law traditionally employed in the United States "have not worked and cannot be made to work." 1959 DUKE L.J. at 174.

${ }^{98} C f$. Aetna Life Ins. Co. v. Dunken, 266 U.S. 389 (1924); Home Ins. Co. v. Dick, 281 U.S. 397 (1930); John Hancock Mut. Life Ins. Co. v. Yates, 299 U.S. 178 (1936). See also Clay v. Sun Ins. Off. Ltd., 28 U.S.L. WEeK 4452 (U.S. June 13, 1960).

9926 U. CHI. L. REv. at 44-47.

${ }^{100} I d$. at 42 . We are told that the forum does not "conceivably" have "any interest in the application of its governmental policy" if it was without an interest at the time of the occurrence of the events giving rise to the controversy. Id. at 46 . The repetition of this statement in various forms, $i d$. at $42-47,81$, does not explain why a strong local interest at the time of institution of suit should not suffice to support the application of local law.

101 Fourteenth amendment $\S 1$.

${ }^{102}$ Art. IV, \& 1.

${ }^{103} 25$ U. CHI. L. REv. at 258.

104 Art. IV, §2.

${ }^{105}$ Fourteenth amendment, $\S 1$. 
roots in essentially intrastate considerations, and are not specially designed to enable residents to prevail over non-residents. ${ }^{106}$ When Professor Currie says that a court should effectuate the governmental interests of the forum he means no more than that it should effectuate such policies to the extent that substantial local contacts of a contemporaneous nature afford a reasonable basis for doing so. Up to this point, at least, his approach is one which would have provoked no serious demurrer on the part of Ulrich Huber.

It is at this point, however, that Professor Currie takes the helm while tossing overboard the compasses, sextants, and other navigational aids which centuries of effort have devised. That is to say, he proceeds to deal with the problem of governmental interest as if conflict-of-laws theory and practice had been totally unconcerned with this problem in the past. ${ }^{107}$ His treatment of governmental interest is on the whole fairly reasonable in his case study of married women's contracts, but only if one accepts his assumptions about the nature of the interests involved. ${ }^{108}$ The analysis is less reasonable in his case study of survival statutes. ${ }^{109}$

In general, the position expressed in his writings appears to be that the courts should give effect to "specific, limited"110 interests, and they that should not seek to give effect to interests of a long-term or "general" dichotomy is not meaningfully elaborated. Is the "specific, limited" interest to be vindicated the one immediately at issue in the litigation, or is it a competing domestic interest which is also specific and limited, but which is deemed weightier than the domestic interest involved in the litigation? Professor Currie did not come to grips with this question in the earlier articles in which his choice-of-law theory is developed.112 In a more recent article he noted in

${ }^{106}$ Suppose that Massachusetts preserves the contractual incapacity of married women, and that a Massachusetts creditor makes a contract with a married woman whose domiciliary state has abolished the rule of contractual incapacity. Professor Currie would have a Massachusetts court decide in favor of the Massachusetts creditor. In doing so the court would not be applying the internal law of Massachusetts, if by internal law we mean the law that is applied when all the contacts are local. But the court would be applying a genuinely indigenous policy - the general policy of Massachusetts in favor of the security of commercial transactions entered into by its residents.

${ }^{107}$ See particularly 1959 DUKE L.J. at 173-74.

${ }^{108}$ It has been noted that Professor Currie overlooks the complexity of the interplay of local interests in such a case, and that Massachusetts might perhaps as reasonably conclude that its self-interest in this regard is better served by adherence to the venerable place-ofmaking rule, see p. 480 supra, supplemented by use of the venerable doctrine of "public policy" to protect resident married women in respect to their out-of-state contracts. $C f$. Kramer, Interests and Policy Clashes in the Conflict of Laws, 13 RuTGERS L. REv. 523, 539-40 (1959).

${ }^{109}$ See note 45 supra.

${ }^{110} 26$ U. CHr. L. Rev. at 82.

111 Ibid.

112 In his article on married women's contracts Professor Currie toyed with the idea that a court "shrewdly" concerned with advancement of local interests might jettison the particular local interest involved in the litigation on the theory that a holding adverse to this interest 
passing, but with apparent approval, that the deliberate fabrication of choiceof-law rules which benefit the largest number of local residents, albeit at the expense of other local residents, is " $\mathrm{a}$ technique well established in the conflict of laws;"113 and in other recent articles he has paid increasing attention to this problem. ${ }^{114}$ At the same time, however, he has revealed exaggerated fears concerning the degree to which the equal protection clause circumscribes this kind of interest-weighing. ${ }^{115}$

would benefit the state in the great majority of cases. See 25 U. CHr. L. REv. at 247 . However, in a later article he stated as follows: "Assuming ... that the obfuscations of the system were cleared away, there might conceivably be situations in which a court might rationally conclude that securing a specific, limited interest of its own state is less important than advancement of the general interest of the state, and of the states generally, in maintaining a reasonably stable and civilized general legal order. ... Even so, I find it difficult to escape the conclusion that such an appraisal and calculation is essentially a political function, and that neither the science of jurisprudence nor its offspring, the conflict of laws, can afford much guidance for its performance." 26 U. CHI. L. REv. at 82. See also notes 121, 122 infra.

${ }^{113}$ Currie, The Constihution and the "Transitory" Cause of Action, 73 HaRv. L. REv. 36 (Part I), 268 (Part II), at 57 (1959).

${ }^{114}$ See Currie, The Silver Oar and All That: A Siudy of the Romero Case, 27 U. CHr. L. Rev. 1, 65-75 (1959); Currie \& Lieberman, Purchase-Money Mortgages and State Lines: A Shudy in Conflict-of-Laws Method, 1960 Duke L.J. 1, 43.

11573 HARv. L. REv. 36, 44-66 (1959). His argument concerning the equal protection clause is essentially as follows: Assume that a state wishes to create an action for wrongful death, but in a manner which will minimize the possibility that citizens of other states will advance claims against local citizens; it is believed by the legislators that claims based upon out-of-state accidents are likely to be brought in the ordinary case by a noncitizen against a citizen; with a view to barring such claims, and at the same time avoiding problems under the privileges and immunities clause, a statute is enacted which simply provides that an action for wrongful death may be brought within the state only if the fatal accident took place within the state; there is no consequent discrimination against noncitizens as such because under the statute their rights and disabilities are identical with those of citizens; an incidental effect is that the statute prevents suit locally in respect of the "occasional citizen ... who might be killed elsewhere," but the legislature is prepared to pay this price to achieve its objective-it is prepared, that is, "to take the bitter with the sweet." Id. at 56-59. After acknowledging, as noted in the text, that such a "technique" is commonly employed by judges in the development of choice-of-law rules, Professor Currie concludes that the statute in question is void under the equal protection clause because the giving of a remedy when a citizen is wrongfully killed within the state and the withholding of a remedy when a citizen is killed without the state represents an "arbitrary and capricious" classification. $I d$. at 60 . The authority mustered in support of this conclusion, $i d$. at 61 , is negligible.

This conclusion concerning the operation of the equal protection clause is suggested by Professor Currie in the course of analysis of what he considers to be a "paradox" in the opinion of the Supreme Court in Hughes v. Fetter, $341^{-}$U.S. 609 (1951). See 73 Harv. L. REv' at 37. In this case, involving a Wisconsin statute which, as construed by the highest court of the state, was similar in its operation to the hypothetical statute described in the previous paragraph, the Supreme Court held that refusal to entertain a cause of action based on the Illinois wrongful death statute, arising from a fatal accident in Illinois, was a violation of the full faith and credit clause. In a footnote, the Court observed that the case was not one in which Wisconsin was seeking to apply its own law "to measure the substantive rights involved," 341 U.S. at 612 n.10; and Professor Currie properly draws the implication that the Court recognized that, even in a case involving an out-of-state accident but otherwise significant local contacts (which were seemingly present in this instance), Wisconsin could apply its internal law if it 
As for the long-term or "general" interests which a court is not to take into account in a conflict situation, these apparently include benefits which accrue or are thought to accrue from such policies as "the policy of promoting a general

chose to do so. 73 HaRv. L. Rev. at 37, 44-45. A relatively simple explanation of this "paradox" seems possible. As Professor Currie recognizes, it was at all times assumed in the litigation that only the substantive law of Illinois was or could be applicable. Under these assumptions, the application of Wisconsin substantive law would have been violative of the full faith and credit clause, and the Court took the further step of holding that refusal to apply the Illinois law, the doctrine of forum non conveniens being unavailable, was also violative of the full faith and credit clause. It would not be inconsistent with the holding or the reasoning to permit Wisconsin to apply its own substantive law in a case where the local interest in doing so,based upon substantial local contacts, is properly asserted.

Thus, if the decedent and all living persons with any conceivable interest in the litigation are Wisconsin residents, there is good reason to believe that Wisconsin would be free to apply the maximum recovery provision of its own wrongful death statute, whether higher or lower than that of the state where the fatal accident occurred; and that Wisconsin would be free to determine for itself whether the recovery should be subject to the claims of the decedents' creditors or whether it should go to certain statutory beneficiaries free from such claims. Similarly, there is good reason to believe that, where only local residents are involved, Wisconsin can constitutionally abolish the action for wrongful death in respect of local and out-of-state accidents alike. Dismissal of a Wisconsin action under a statute so designed would not be on jurisdictional grounds but on the merits, and presumably would bar a wrongful death action elsewhere. Dismissal of the action in Hughes v. Fetter was under a Wisconsin statute at all times conceived by the parties and the several courts that considered the case to be a local door-closing enactment not intended to affect any substantive rights that might have been acquired under the law of another state; certainly there was no reasonable basis for the Supreme Court of the United States to view the statute otherwise than in this way.

As noted, Professor Currie has suggested that a statute which is in form a door-closing rule, and which does not purport to affect any substantive rights claimed under a foreign rule, might nevertheless have been enacted on the theory that in the typical case it would effectively shield residents of the forum against claims pressed by nonresidents; and that, whatever its other constitutional infirmities might be, such a statute should not be deemed invalid under the full faith and credit clause since it is no less designed for the regulation or protection of important local interests than the more clearly substantive measures cited in the previous paragraph. Hence the footnote in Hughes v. Fetter suggesting that Wisconsin may be free in a proper case to apply its internal law "to measure the substantive rights involved" represents a "paradox" to Professor Currie.

Regarding this argument, it may be noted first of all that Professor Currie does not contend that the Wisconsin door-closing rule was devised with a view to the protection of local interests; in fact he suggests that it was the more or less accidental product of ineptitude by the Wisconsin Supreme Court. 73 HARV. L. REv. at 50-52. But even if the Wisconsin rule was designedly protective in character rather than merely a quasi-jurisdictional measure devoid of substantive content, it was not presented in this fashion to the Supreme Court. To read Hughes v. Fetter as a holding regarding the effect or validity of a rule designed for the regulation or protection of local interests is to create a "paradox" where none really exists.

This obvious resolution of the "paradox" is apparently unacceptable to Professor Currie. To him, the reliance of the Supreme Court upon the full faith and credit clause was "unnecessary and confusing," 73 HARv. L. REv. at 61 . His view is that the "results reached by the opinion and the footnote are irreconcilable," $i d$. at 62 , unless the holding is deemed to have been based upon the equal protection clause (a basis not mentioned by the Court nor suggested at any stage of litigation) rather than the full faith and credit clause. Professor Currie does not consider the implications of this restrictive view of the equal protection clause for interestweighing in conflict situations, nor does he consider the broader problem of its implications generally for attempted classification by judicial or legislative action.

Professor Currie returns to the equal protection clause in a more recent article, Purchase- 
legal order, that of fostering amicable relations with other states, that of vindicating reasonable expectations, and so on."116 In large measure Professor Currie seems to identify long-term interest with the type of benefit which comes generally from uniformity of outcome. It is on the assumed benefit of uniformity that his distrust centers; it is for seeking this assumed benefit that he is most sharply critical of that "wretched and spurious" creation-"the taught system of choice of law."117 The interest of a state in achieving uniformity may indeed in many instances be nebulous or non-existent, and the uncritical pursuit of uniformity in such situations has undoubtedly led the courts to undesirable results. But in other instances the advantages of uniformity may be fairly obvious; in such instances it would be incongrous for the courts to pursue other local interests while systematically eschewing pursuit of the strong local interest in uniformity.

If governmental interest from the vantage point of a state judge is to be of service as an analytical tool in the solution of choice-of-law problems, it is particularly important that a balanced view of governmental interest be maintained. The undeviating pursuit of "specific, limited"118 interests may be as treacherous as the undeviating pursuit of uniformity. One need only catalogue such classic arguments as the need for a system which operates for the mutual convenience of rival sovereignties; the wisdom of avoiding measures which invite retaliation; ${ }^{119}$ and the problem whether a system of justice can long endure if injustice is systematically practiced upon foreigners. The calculation of local interest must take account not only of these general considerations, but also

[footnote 115 continued from preceding page]

Money Mortgages and State Lines: A Shudy in Conflict-of-Laws Method, 1960 Duke L.J. 1 (with Mark S. Lieberman), where he deals with a statute of North Carolina construed by the Supreme Court of that state as depriving the North Carolina courts of jurisdiction to entertain an action by a mortgagee under a purchase money mortgage for a deficiency judgment irrespective of the location of the land or of the place where the note and mortgage were executed. The court emphasized that the statute did not govern the substantive rights of the parties but only the jurisdiction of the local courts. The result, as Professor Currie points out, was to leave North Carolina residents vulnerable to suit in other states, but he notes also that such an approach may have been thought desirable on the theory that, on balance, the highest degree of protection for local residents, including local residents who became obligated in other states, would be achieved by a general removal of local jurisdiction to consider such suits. See id. at 41-55. Such a statute, he says, does not contravene the equal protection clause because "all residents ... are treated alike by the North Carolina courts." Id. at 53. The fact that they are not all treated alike by the North Carolina legislature is apparently considered by him to have no bearing on the operation of the equal protection clause.

1161959 DUKE L.J. at 181. See also 26 U. CHI. L. REv. at 82, and note 121 infra.

11710 STAN. L. REv. at 241.

11826 U. CHr. L. REv. at 82.

${ }^{119}$ In developing a particular choice-of-law rule in the first of his case studies, Professor Currie takes account of the possibility that a contrary rule might "lead to unpleasant reprisals." 25 U. CHI. L. REv. at 256 . This is done in an isolated instance, without consideration of the implications of such an approach for his view that a court should eschew considerations of a general or long-term character. 
of the peculiar conditions of our national union-of the degree to which the economies and fortunes of the several states are interdependent-of the degree to which our commerce is dominated by nation-wide corporations which do business in many or all states, which have employees or agents in many or all states, and which are owned by people residing in many or all states. It is quite apparent that there exists a common, or national, interest which cannot realistically be ignored in local appraisals of local interest. ${ }^{120}$

Does Professor Currie believe such considerations to be unimportant? His writings do not provide a ready answer. One passage indicates that he regards them as of relatively minor importance in comparison with the other considerations which enter into the determination of governmental interest, ${ }^{121}$ but this view seems to be qualified elsewhere ${ }^{122}$. Again, it may be noted that Professor Currie's skepticism seems to be directed primarily to the goal of uniformity for the sake of uniformity, and not to a particularized pursuit of uniformity which rationally advances the interests of the several states. What is crucial is his concession that there are situations in which the policies of a state should, as he puts it, "yield" to those of another state. ${ }^{123} \mathrm{He}$ recognizes that

${ }^{120}$ Cf. Kramer, Interests and Policy Clashes in Confict of Laws, 13 RUTGers L. Rev. 523 " 561-64 (1959); Katzenbach, Conflicts on an Unruly Horse: Reciprocal Claims and Tolerances in Interstate and International Law, 65 Y ALE L.J. 1087 (1956) (passim); Cheatham \& Reese, Choice of the Applicable Law, 52 Colun. L. REv. 959, 962-64 (1952). See also EHRENzweig, CONFLict of LAWS 17-19 (1959).

121 "A choice-of-law rule does express a policy, but it is not of the same order as the social and economic policies which are normally developed by a state in the pursuit of its governmental interests and the interest of its people. Viewed in the most favorable light, the policy is that the state, as a member of the community of states, will join in a fairly general movement which imposes a degree of restraint upon its sovereignty and upon the pursuit of its selfish interests, to the end that the result of a case will not depend capriciously upon where it happens to be brought and that expectations founded upon one system of law will not be frustrated by the application of another. This is but a mild, tentative, and self-denying policy. It implies the yielding, from time to time, of specific governmental policies for the sake of a general legal order. The imperative conception of the choice-of-law rule leads to a quite unacceptable paradox: the highest priority is to be given to that rather general and diffident policy which requires that specific, carefully formulated social and economic policies be subordinated to the contrary policies of a foreign state.

"I do not exaggerate when I say that the imperative concept, especially as it has been developed in the judicial notice statutes, gives the highest priority to that one class of laws which, of all classes, has least to do with furthering the gowernmental interests of the state." On the Displacement of the Law of the Fortm, 58 Colum. L. REv. 964, 1007 (1958). (Emphasis added.)

122 "I have been told that I give insufficient recognition to governmental policies other than those which are expressed in specific statutes and rules: the policy of promoting a general legal order, that of fostering amicable relations with other states, that of vindicating reasonable expectations, and so on. If this is so, it is not, I hope, because of a provincial lack of appreciation of the worth of those ideals, but because of a felt necessity to emphasize the obstacles which the present system interposes to any intelligent approach to the problem. Let us first clear away the apparatus which creates false problems and obscures the nature of the real ones. Only then can we effectively set about ameliorating the ills which arise from a diversity of laws by bringing to bear all the resources of jurisprudence, politics, and bumanism-each in its appropriate way." 1959 DukE L.J. at 181.

${ }^{123}$ See p. 474 supra. 
such a course could be most advantageous to the several states concerned-and declares that the states might appropriately seek such mutual advantage through interstate compacts, although he believes that Congress could deal with the matter more effectively. ${ }^{124}$ In other words there are reasons of governmental interest for pursuing such a course. The essence of his position is not a denial that governmental interest is involved; it is an insistence that this conceded aspect of governmental interest should be dealt with by legislative action and not by the courts.

Thus we return to the arguments, noted in the previous section, which he gives for this position: the alleged incompetence of the courts to deal with such problems, and qualms as to whether courts are the proper agencies to deal with such problems in a democratic society. These arguments have already been examined but an additional point may be made now. Both arguments seem to derive largely from Professor Currie's view that the function of the courts under traditional choice-of-law practice is the resolution of interstate conflicts. $\mathrm{He}$ is aware of, and professedly reconciled to, the interest-weighing which accompanies judicial law-making on the purely intrastate level. As has been seen, he draws the line at judical interest-weighing when the respective interests being weighed are those of the forum state on the one hand and those of some foreign state on the other. The fallacy is in the assumption that this is the dominant and characteristic aspect of the process of choice of law-in the assumption that when a particular foreign interest is preferred to a particular local interest, the courts of the forum have necessarily sacrificed the interests of the forum. As has been observed, it is probably more likely that the result is actually a vindication of the over-all governmental interests of the forum, and that the particular local interest involved in the litigation has been defeated not so much by a competing foreign interest as by competing local interests which may be specific or quite general in character. Thus the interest-weighing which takes place in the typical conflict case is not necessarily different in kind from that which takes place in a wholly intrastate case.

The problem of the false-conflict situation becomes especially relevant at this point. Professor Currie has shown convincingly that by systematic analysis of a choice-of-law problem from the point of view of governmental interest it is possible to detect and eliminate the cases of false conflict. But if an artificially limited concept of governmental interest is employed, the effect would be the creation of conflicts which do not really exist-in other words, false conflicts. If, for example, uniformity of result is desirable in a particular class of cases, and if it can be achieved by a particular choice-of-law rule, it is difficult to see why the courts should abjure both the objective and the rule. It is not contended herein that the traditional choice-of-law rules rationally advance governmental interest in all cases; obviously they do not. But the situation would hardly be improved by holding the courts to the duty of resolving

124 See 25 U. CHI. L. REv. at 263-68. 
conflict problems in accordance with standards from which there have been deliberately excluded considerations of conceded importance in any rational evaluation of governmental interest. Even if the excluded considerations were best dealt with by legislative action, it is not clear why, pending such action, the courts should proceed irrationally. ${ }^{125}$

In fairness to Professor Currie, it should be emphasized that he seems to be primarily interested in developing techniques for fruitful analysis in terms of governmental interest rather than in defining the specific types of interests that a court may properly consider. As noted earlier, the dichotomy of shortterm and long-term interests is not systematically developed in his writings. To the extent indicated, however, he has stressed the former and seriously disparaged the latter; and he has clearly expressed the view that, however reasonable and desirable it may be to subordinate "specific, limited" interests of a state to interests of a long-range nature, decisions in this regard are a legislative rather than a judicial responsibility. It is not certain that this represents or will represent his ultimate position. In his most recent articles he has shown increasing awareness that the governmental interest of the forum may often be a composite of competing interests. To the extent that it is recognized that the effectuation of one local interest may necessarily entail the defeat of others,

125 Reference has already been made to the variety of interests-certainly not all of them immediate or short-term in nature- which may call for subordination of the particular local interest involved in litigation over a married woman's contract when the forum itself adheres to the common law rule of marital disability. See pp. 479-80 supra. And see note 45 supra for a suggestion of the complexity of the interests that may be involved when the problem is whether to accord recognition to a foreign statute governing the survivorship of tort claims.

Examples of this sort can easily be multiplied. Thus the resident descendants of a nonresident decedent may lay claim to his personal property located within the forum on the basis of the forum's rules of distribution, but it may be thought wiser to grant such persons the lesser portion accorded them by the law of the decedent's domicile, on the theory that the interests of the forum will be best advanced if the rule of the domicile generally governs as to such matters. Cf. Goodrich, Conflict of Laws 504 (3d ed. 1949). Similarly, despite otherwise sufficient local contacts which might support the claims of local residents to chattels situated within the forum, it may be thought wiser in some instances to recognize adverse security interests created by foreign law. Cf. Stumberg, Challel Security Transactions and the Conflict of Laws, 27 Iowa L. REv. 528 (1942). So too, when a contract having multistate aspects is the basis of an action against a corporation organized and doing business within the forum, an otherwise sound defense based upon local law may conceivably be denied on the theory that the general self-interest of the forum will be better served if such a corporation, which is well able to look after itself, is bound by the terms of a contractual stipulation that foreign law should govern. See Traynor, Is This Conflict Really Necessary?, 37 TEx. L. REv. 657, 674 (1959). Cf. Ehrenzweig, Adhesion Contracts in the Conflict of Lawes, 53 Conom. L. Rev. 1072 (1953).

As has been noted, Professor Currie's dichotomy of short-term and long-term interests is not clearly delineated, and it is difficult to predict in advance how he would classify a particular interest. What is crucial, however, is his concession that there are interests which, though long-term and therefore not proper subjects for judicial consideration under his system, are nevertheless so highly important-there are, he tells us, "areas" of "critical need"-that he believes the major "energies" of scholarship in the field of conflict of laws should be "diverted to the formulation and iustification of specific legislative programs." $25 \mathrm{U}$. CHr. L. REv. at 267-68. Again, it must be emphasized that the objection is not to legislative attempts to deal with such problems (the feasibility of the legislative approach is not in issue here), but to Professor Currie's insistence that the courts should act if as such problems do not exist. 
the dichotomy of short-term and long-term interests becomes increasingly meaningless. However, concurrently with Professor Currie's growing attention to these problems, he has, as previously noted, argued for a construction of the equal protection clause which would seriously circumscribe interest-weighing in a conflict situation. If he can surmount this self-imposed obstacle and take realistic account of the range of intrastate interests which press upon a court in a conflict case and of the need to choose among them, he may find that many of the formal choice-of-law rules are not at all unreasonable in the manner in which they make the choice.

The point has been made that if a broad view is taken of governmental interest the incidence of true-conflict situations is probably a good deal smaller than Professor Currie believes. But even under such a broad view of governmental interest, it is undoubtedly the case that true-conflict situations exist in substantial measure. When a true conflict, thus defined, presents itself, Professor Currie seems to this writer to be on sound ground in urging that the forum should decide the controversy in accordance with its own interests. Such a view seems to be inherent in the work of earlier writers who have argued for an approach to choice-of-law problems based on the rational effectuation of governmental policies, and who have argued, in line with this view, that uniformity should not be sought in situations where uniformity does not serve significant ends. ${ }^{26}$

However Professor Currie, despite his unduly narrow conception of the judicial function, has provided useful clarification by his bold approach to the problem of the "true-conflict" case. The power of the states to adopt policies reflecting regional predilections is a highly prized attribute of our federal system,

${ }^{126} C f$. Stumaerg, Conflict of Laws 205-07 (2d ed. 1951); Cheatham \& Reese, Choice of the Applicable Law, 52 Colum. L. Rev. 959, 965-69, 978-80 (1952); Harper, Policy Bases of the Conflict of Laws: Reflections on Rereading Professor Lorenzen's Essays, 56 YALE L.J 1155, 1159-63, 1170-71 (1947); Kronstein, Crisis of "Conflict of Laws," 37 GEo. L. J. 483, 51213 (1949); Lorenzen, Territoriality, Public Policy and the Conflict of Laws, 33 YaLE L.J. 736, 748-51 (1924), reprinted in LORENZEN, SELECTED ARTICLES ON THE CONFLICT OF LAWS 1, 14-18 (1947); Rheinstein, The Place of Wrong: A Shudy in the Method of Case Law, 19 TuL. L. REv. 4, 28-31 (1944); Yntema, The Hornbook Method and the Confict of Laws, 37 Yale L.J. 468, 479 (1928). Cf. also Katzenbach, Conflicts on a Unruly Horse: Reciprocal Claims and Tolerances in Interstate and International Law, 65 YALE L.J. 1086, 1097-1101,112728 (1956); Paulsen \& Sovern, "Public Policy" in the Conflict of Laws, 56 Coluss. L. Rev. 969 (1956). For views to the same effect in an article which appeared at approximately the same time as Professor Currie's initial writings on the subject, see Shuman \& Prevezer, Torts in English and American Conflict of Laws: The Role of the Forum, 56 MICH. L. REv. 1067 (1958). Persons commenting on Professor Currie's writings have agreed that the forum should effectuate its own interests in the "true conflict" case, but without full agreement in all instances with his methods for determining the existence of the "true conflict" case. See Kelso, The Process of Analyzing Choice of Law Problems, 1959 WASH. U.L.Q. 37, 55-63; Kramer, Interesis and Policy Clashes in Conflict of Laws, 13 RuTgers L. Rev. 523, 560-64 (1959); Traynor, Is This Conflict Really Necessary?, 37 TEx. L. REv. 657, 673-75 (1959). See also Ehrenzweig, The Lex Fori in the Conflict of Laws-Exception or Rule?, 32 Rocky Mr. L. REv. 13 (1959); Ehrenzweig, The Lex Fori-Basic Rule in the Conflict of Laws, 58 Mrcm. L. REv. 637 (1960); Sumner, Choice of Law Rules: Deceased or Revived?, 7 U.C.L.A.L. Rev. 1, 24 (1960). 
and it is inappropriate for the courts of a state to assume a unifying or federalizing role without regard to the rational demands of local interest broadly construed. There is no compelling reason for a single choice-of-law rule to be applied by the courts of, say, states $\mathrm{X}$ and $\mathrm{Y}$, when both these states have substantial contacts with a particular controversy; when these states also have significantly divergent policies; and then when pursuit by each state of its own policies would not produce unfairness, or a condition of mutual inconvenience, or prejudice to the national interest generally. Subject to a caveat noted below, Professor Currie has convincingly demonstrated that the dominant course of decision by the Supreme Court leaves the door open to such a pluralistic approach to conflicts problems.

Even under the indicated circumstances there is a place, indeed a need, for uniform choice-of-law rules. Thus, states $\mathrm{X}$ and $\mathrm{Y}$, having substantial contacts with a particular controversy, may very well pursue local interest, but a disinterested forum requires some criterion other than local interest for choice of the applicable law; it needs the best choice-of-law rule it can get. However, the fact that a particular choice-of-law rule may appropriately be applied by the disinterested forum does not mean that it is equally appropriate that the same rule should be applied in all cases by courts sitting in states $\mathrm{X}$ and $\mathrm{Y}$. It is regrettable that Professor Currie chooses not to concern himself with the problem of the disinterested forum, but his essays convincingly demonstrate the impropriety of attempting to foist a common choice-of-law rule in all situations on states $\mathrm{X}$ and $\mathrm{Y} .{ }^{126 \mathrm{a}}$

126a The revisers of the Restatement appear to be adhering to the principle that a single choice-of-law rule shall govern in all states, while making substantial changes in particular choice-of-law rules, especially in cases of contract. See Restatedent (SECOND), Conflict of Laws, (Tent. Draft No. 5, 1959) (property), (Tent. Draft No. 6, 1960) (contracts). It remains to be seen how the revisers will deal with the problem of public policy. See p. 479 infra. It is not clear why the judicial branch of a state government should be rigidly bound by a standard of uniformity which no one would seriously propose for the legislative branch; thus no one would seriously propose to a legislature that it should forego local interest in favor of uniformity even in those instances where no discernible benefits, or at the most very weak benefits, are derivable from uniformity. In fact, the standard of uniformity would be largely meaningless under the proposed general rule applicable to contracts, which would make questions of validity and performance subject to the law of "the state with which the contract has its most significant relationship." (Tent. Draft No. 6, $\S 332$ ). Cf. $\$ \S 332 \mathrm{a}, 332 \mathrm{~b}, 344 \mathrm{~d}$, comment $c, 346 \mathrm{a}-346 \mathrm{~d}$. See also Tent. Draft No. $5, \S 294$. The forum having substantial contacts with a controversy is allowed enormous leeway under such a rule, and it would be surprising if there were not a tendency to favor local interests that are strongly felt to be in need of protection.

To the extent that the forum is allowed broad discretion under a rule of this character, the ideal of absolute uniformity becomes increasingly unrealistic; rather the rule, which purports to be a uniform choice-of-law rule, becomes a device facilitating preferment for local interests. The particular contracts rule to which reference has been made may well be as good a rule as can be formulated for the disinterested forum, but it falls short of being an accurate expression of the pattern of judicial conduct that is followed, or that can be expected to be followed, in the interested forum. Indeed, the revisers appear to recognize this, since they declare that "the forum can be expected to be more conscious of its own local policies than of those of another state." Tent. Draft No. $6, \S 332 a$, comment $g$. 
As for the "false-conflict" cases, others have dealt effectively with this problem before Professor Currie, ${ }^{127}$ but here again, despite the unduly narrow scope he would allow to judicial interest-weighing, his analytical method is particularly useful in demonstrating the character of the problem. Here he agrees on the need for uniformity, but rejects the kind of uniformity that is sometimes provided by the traditional system. Thus if a Maine creditor and a Maine married woman execute a contract in Massachusetts, it is not clear why any court should invalidate the contract solely on the basis of the internal policy of Massachusetts; if, as is likely, Massachusetts is really unconcerned with the legal consequence of this particular act within its borders, the application of Massachusetts law would defeat the justifiable expectations of the parties without rationally advancing the interests of any state.

To a considerable extent the doctrine of public policy in the traditional system of choice-of-law lends itself to the vindication of an enlightened self-interest on the part of the forum. But some significant shortcomings must be noted. The system, at least as embodied in the Restatement, affords recourse to public policy only grudgingly, ${ }^{128}$ non-indulgence is often to be thought the better part of judicial virtue. ${ }^{29}$ Moreover, the concept is essentially a negative one; public policy can be used to reject a claim (or defense), but ordinarily is not considered to be a proper foundation for a claim. Also, the formulation of the doctrine is confusing; in fact, public policy seems usually to be invoked when the forum has significant contacts with the controversy, so that the local public policy becomes, in effect, the substantive law of the case. But public policy is not thought of as a device for applying local substantive law, with the result that the doctrine is sometimes invoked when it should be ignored (e.g., by the disinterested forum), or ignored when it should be invoked. ${ }^{130}$

A caveat is in order concerning the constitutional limitations on the pursuit of self-interest in a true-conflict situation. Abundant reference has already been made to the prohibition of discriminatory practices against citizens of other states. An additional problem, which has also been touched upon to some

${ }^{127}$ E.g., Cavers, The Two "Local Law" Theories, 63 HARv. L. REv. 822, 827-28 (1950); Freund, Chief Justice Stone and the Confict of Laws, 59 HARv. L. REv. 1210, 1216-25 (1946); Griswold, Renvoi Revisited, 51 HaRv. I. Rev. 1165, 1188-1208 (1938); Hancock, Choice-of-Law Policies in Multiple Contact Cases, 5 U. Toronto L.J. 133 (1943); Harper, supra note 126, at 1171-74; Sohn, New Bases for Sohtion of Conflict of Laws Problems, 55 Harv. L. Rev. 978 (1942). Cf. Cavers, A Critique of the Choice-of-Law Problem, 47 HARv. L. Rev. 173, 189-93 (1933); Katzenbach, supra note 126, at 1119-27. Judge Traynor has made some cogent remarks on the "false conflict" problem since the publicizing of Professor Currie's thesis. See Traynor, supra note 126, and before that, acting in his judicial capacity, he had helped to solve some "false conflict" problems himself, perhaps most notably in Grant v. McAuliffe, 41 Cal. 2d 859, 264 P.2d 944 (1953), discussed at pp. 469-72 supra. Cf. Stumberg, "The Place of the Wrong": Torts and the Conflict of Laws, 34 WASH. L. REv. 388 (1959).

${ }^{128}$ RESTATEATENT (FIRST), Confuct of Laws $\$ 612$, comment $c$ (1934).

${ }^{129}$ See, e.g., Goodrich, Public Policy in the Lawe of Conflicts, 36 W. VA. L.Q. 156 (1930).

${ }^{130}$ See Lorenzen, supra note 126; Paulsen \& Sovern, supra note 126. 
extent, involves the nature of the local contacts which justify the forum in applying its own law. In his article, The Constitution and the Choice of Law: Governmental Interests and the Judical Function, ${ }^{131}$ Professor Currie vigorously advances the following thesis: (1) When the forum lacks a substantial contemporaneous interest in the operative facts of a controversy it is precluded from applying its own law by virtue of the due process clause and the full faith and credit clause. (2) Having such an interest, the forum may effectuate it without interference from the Supreme Court even though another state has a similar interest; the Supreme Court should not choose between the states unless and until Congress implements the full faith and credit clause by appropriate legislation. ${ }^{132}$ Professor Currie recognizes that the second part of the thesis has not always found recognition in the cases, but he thinks it represents an "emerging principle."133 It is submitted that the first part needs to be qualified and that the second is of doubtful merit either as a statement of an emerging principle or as a prescription for desirable constitutional development.

A case illustrative of the first part of the thesis is John Hancock Mutual Life Ins. Co. v. Yates, ${ }^{134}$ which involved an insurance contract made in New York on the life of a man who, with his wife, resided in that state. The insured died in New York. Thereafter the widow became a resident of Georgia, and sued on the policy in its courts. Obviously Georgia, with a policy more favorable to insurance beneficiaries than New York, had a substantial interest in the case: the plaintiff was not only a resident of the state, but the kind of resident who is particularly likely to become a public charge if unsuccessful in such litigation. Nevertheless the Supreme Court held that Georgia was required, by virtue of the full faith and credit clause, to give effect to the New York rule.

Can the result be rationalized as the product of a "weighing" process in which New York's interest prevailed because deemed more substantial than Georgia's interest? The difficulty with this view is that the result in such a case probably would be the same if, at the time of suit, the first state has long since ceased to have any actual interest because of the removal therefrom of all the parties and their businesses and properties. Perhaps a more plausible rationalization is that the second state, despite its substantial interest, may not apply its own law because to do so would unfairly defeat the reasonable expectations of the parties. In such a case, state judicial action which contravenes the full faith and credit clause probably contravenes as well the due process clause of the fourteenth amendment. ${ }^{135}$ Typically, in such cases, the interest that the forum

13126 U. Cer. L. REv. 9 (1958).

${ }^{133} I d$. at 13 .

132 Id. at $13-14$.

134299 U.S. 178 (1936).

${ }^{135}$ It has never been resolved whether the "public acts" of a state embrace its judge-made law. Compare 26 U. CHI. L. REv. at 15-16 with Nadelmann, Full Faith and Credit to Judgments and Public Acts, 56 Mrcn. L. Rev. 33, 75 (1957). See also Jackson, Full Faith and Credit-The Lawyer's Clause of the Constitution, 45 Coudn. L. Rev. 1, 13 (1945). If this question should be answered in the negative, the full faith and credit clause will to this extent have a narrower scope than the due process clause. A discussion of this and other possible distinctions between the two clauses would not be germane to the argument developed in the text. 
has at the time of suit did not exist when the action was taken which gave rise to the controversy, ${ }^{136}$ although, as Professor Currie recognizes in a later article, there may be cases in which the "police power" of the forum may support the application of local law despite the lack of a contemporaneous interest. ${ }^{137}$ On the other hand, situations can be envisaged in which a strong interest of the forum from the inception of the controversy might not overcome the objection that the application of the law of the forum would be grossly unfair. ${ }^{138}$ In any event, whether a substantial local interest is sufficiently "legitimate" to warrant the injection of local law into this type of case is a question on which the traditional resources of the law of conflict of laws can shed much light, precisely because the human formulators of the traditional doctrines were concerned-one is tempted to say inevitably concerned-with the fulfillment of reasonable expectations and problems of fairness generally. ${ }^{139}$

There are other cases in which the forum was held to the duty of applying a foreign rule, despite the presence of an interest which was both substantial and contemporaneous, and despite the fact that the application of local law would not have frustrated the reasonable expectations of the parties or been otherwise grossly unfair. Some of these cases, like Broderick v. Rosner, ${ }^{140}$

${ }^{136}$ See Weintraub, Due Process and Full Faith and Credit Limitations on a State's Choice of Law, 44 Iowa L. REv. 449, 457-60 (1959).

${ }^{137}$ Currie \& Lieberman, Purchase-Money Mortgages and States Lines: A Study in Conflictof-Laws Method, 1960 DuKe L.J. 1, 51 n.164.

${ }^{138}$ Consider this hypothetical case: $A$ section of state $X$, which juts into state $Y$, is traversed by a road much used by citizens of state $Y$ traveling between different points of their own state. There is no legal speed limit, and much speeding, with a resulting high accident rate. The pleas of state $Y$ to state $X$ for the establishment of a safe speed limit on the road in question have been ignored. State $Y$ thereupon enacts, and gives abundant publicity to, a statute providing that any person driving in excess of 60 miles per hour on the road shall be deemed, conclusively, to have been negligent. May state $Y$, under this statute, impose liability on a citizen of state $\mathrm{X}$ who had knowledge of the statute?

${ }^{139}$ Cf. 1 Raber, The Conflict of Laws: A Courparative Study 94-95 (2d ed. 1958); Rheinstein, Michigan Legal Shudies: A Review, 41 MICH. L. REv. 83, 92-93 (1942); Rheinstein, The Place of Wrong: A Study in the Method of Case Law, 19 Tolane L. Rev. 4 (Part I), 165 (Part II), at 17-23 (1944).

${ }^{140} 294$ U.S. 629 (1935). This case originated as a suit brought by the New York Superintendent of Banks in a state court of New Jersey to recover certain unpaid assessments levied by him, under the double liability provisions of the New York banking law, against stockholders of an insolvent New York bank. The defendants were 557 stockholders of the bank who happened to be residents of New Jersey. The New Jersey courts dismissed the complaint in compliance with a New Jersey statute which provided, in effect, that such an action could not be entertained unless all the creditors and stockholders of the foreign corporation were brought before the court. It was unmistakably the policy of New Jersey to immunize its citizens against such suits, as far as possible, by setting prohibitive procedural conditions. And it was apparent that substantial local interests underlay such policy, in view of the large number of New Jersey residents who were involved in this suit alone. Nevertheless the assertion of this local interest to defeat the interest of New York was held by the Supreme Court to contravene the full faith and credit clause.

The New Jersey statute had been enacted in 1897, see 294 U.S. at 638, while the banking corporation was not organized under New York law until 1913. MOODY's BANKS AND FINANCE 
and the more recent case of Order of United Commercial Travelers $v$. Wolfe, ${ }^{141}$ probably retain considerable vitality today. ${ }^{142}$

Putting aside those instances in which state judicial action is deemed to transgress against the full faith and credit clause for what may be called due process reasons, it may be noted that at least three possible courses may be followed under the full faith and credit clause when two states (they will be called states $X$ and $Y$ respectively) have substantial contacts with the

1482 (1930). Accordingly, assuming a theoretical reliance by the bank itself upon the statutory liability of its shareholders, there was no basis for a claim of surprise with respect to shares sold directly to New Jersey residents, or distributed so widely (there were in excess of 18,500 shareholders at the end of 1929, id. at 1429) as to make it reasonably certain that a considerable number of New Jersey residents would in due course become owners of such shares. As for the depositors of the defunct bank, who were the intended beneficiaries of the suit, it is at best dubious whether these persons placed actual reliance on the security features of the New York double liability statute; and if they did so rely, it is dubious whether they were reasonably warranted in doing so, for essentially the same reasons that precluded reliance by the bank. The New Jersey statute, it is true, was later condemned by the Supreme Court in its application to the instant case, but a sophisticated prediction regarding the invalidity of a statute under the full faith and credit clause can hardly furnish a basis for a claim of reliance so strong as to render grossly unfair the frustration of the expectations that rest upon such reliance.

The decision in Broderick v. Rosner was handed down three weeks after the one in Alaska Packers Ass'n. v. Industrial Accident Commission of California, 294 U.S. 532 (1935), where the interest-weighing approach had been articulated in the clearest terms. What then of the substantial interest of New Jersey? Mr. Justice Brandeis gave it short shrift. "Obviously," he said, the New Jersey policy of immunizing its residents against suit could not apply-'if there really were" such a policy. 294 U.S. at 644. Professor Currie has no doubt concerning the true nature of the New Jersey policy, and the case is presumably a difficult one for him in view of his general thesis that the Supreme Court should not set aside the assertion of a local policy which is supported by a substantial contemporaneous interest. However, he believes that the Supreme Court decided the case "quite properly," remarking that Niew Jersey had "only itself to blame" because, instead of making a "forthright declaration" of its "protective policy," it had "only pretended a concern for the procedural aspects of such actions, without giving any explanation which would alter the character of the procedural conditions as a merely arbitrary closing of the doors of its courts." The Constitution and the "Transilory" Cause of Attion, 73 HaRv. L. REv. 36 (Part I), 268 (Part II) at 289-90 (1959). It is submitted that the "protective" purpose of the New Jersey statute was as obvious to the Court as to Professor Currie, in contrast to Hughes v. Fetter, where the Courts seems plainly and not unreasonably to have assumed that a protective policy did not underlie the Wisconsin statute there involved. See note 115 supra.

14331 U.S. 586 (1947). A fraternal benefit society, incorporated under Ohio law but licensed to do business in South Dakota, was sued in South Dakota for "benefits claimed to have arisen under the constitution of that society as a result of the death of an insured member who had been a citizen of South Dakota throughout his membership." 331 U.S. at 588. The constitution of the society provided that suits on such claims were to be brought not more than six months after disallowance by the society, and this provision was valid under the law of Ohio. However, a South Dakota statute outlawed such private limitations on the time for bringing suit. The Supreme Court held that it was a violation of the full faith and credit clause for South Dakota to deny effect to the short statute of limitations contained in the constitution of the society. Professor Currie is critical of the result in this case. $26 \mathrm{U}$. CHr. L. REV. at 61-65.

142 For recent articles analyzing the cases arising under the full faith and credit clause, see WeLNTR.AUB, supra note 136; Cheathasr, Federal Conirol of Confict of Laws, 6 VAND. L. REv. 581 (1953); Speidel, Extraterritorial Assertion of the Direct Action Statute: Due Process, Full Faith and Credit and the Search for Governmental Interest, 53 Nw. U. L. REv. 179 (1958). 
same controversy: (1) A course that the Supreme Court has rejected would be to give the clause a "literal" reading which "would lead to the absurd result that, wherever the conflict arises, the statute of each state must be enforced in the courts of the other, but cannot be in its own."143 (2) In cases like Broderick v. Rosner, and Order of United Commerical Travelers $v$. Wolfe, state $\mathrm{X}$ was told that it must follow the rule of state $\mathrm{Y}$. (3) In several cases involving state workmen's compensation laws the Supreme Court has taken the position that states $X$ and $Y$ will be permitted to effectuate local policies without hindrance, ${ }^{144}$ and the court has given indications of a similar approach in other situations. ${ }^{145}$

In cases of the third category, it is clear that the Court is desisting from interest-weighing as such, looking only to the substantiality of the local contacts io determine whether they will support the application of local policies. In zases of the second category, where it is held that one state must in effect apply the rule of another, it may appear that the particular result has been reached by weighing the competing interests of the two states-and support for this view may be found in the opinion of the Court in Alaska Packers Ass' $n$ v. Industrial Accident Commission of California, where it was said that "the conflict is to be resolved ... by appraising the governmental interests of each jurisdiction, and turning the scale of decision according to their weight."1+6 If this view adequately explains the cases of the second category, then the difference between the second and third categories turns upon the judicial weighing of competing state interests in the one and a refusal to engage in such interestweighing in the other. It is submitted that this view of the cases is deceptive, suggesting an inconsistency in the practice of the Court which is more apparent than real.

In cases like Broderick v. Rosner and Order of United Commercial Travelers i. Wolfe, the Court seems impressed, not so much by the "weightier" interest of the state the law of which is chosen, as by the substantial detriment threatined to the national interest by the failure to make such a choice-the term

${ }^{143}$ Alaska Packers Ass'n. v. Industrial Accident Commission of California, 291 U.S. $532,547(1935)$. It is assumed that Congress has not inadvertently legislated this absurdity into being in the 1948 amendment to Section 1738 of the Judicial Code, 28 U.S.C. $\$ 1738$ (1948). See Niadelmann, Full Faith and Credit to Jtdgments and Ptublic Acts, 56 MICH. L. REv. 33, 81-86 (1957); Reese, Full Failh and Credil to Stalutes: The Defense of Public Policy, 19 U. ChI. L. Rev. 339 (1952).

1'4 See Pacific Employers Ins. Co. v. Industrial Accident Comm., 306 U.S. 493 (1939); Carroll v. Lanza, 349 U.S. 408 (1955).

145 E.g., Union Trust Co. v. Grosman, 245 U.S. 412, 415-17 (1918); Grifin v. MrcCoach, 313 U.S. 498, 504-07 (1941); Watson v. Employers Liability Insurance Corporation, 348 U.S. $66,68,72-73$ (1954). Cf. Hanson v. Denckla, 357 U.S. 235, 253-54 (1958); Clay v. Sun Ins. Off. Ltd., 28 U.S.L. WEEK 4454 (U.S. June 13, 1960) (dissenting opinion). The evidence of such an approach is of course particularly strong in cases involving family relations and local taration, although such cases are commonly complicated by the problem of the full faith and credit due to judgments. See authorities collected in Hill, The Erie Doctrine and the Constitution, 53 Niw. U. L. REv. 427 (Part I), 541 (Part II), at 547, n. 180 (1958).

118294 U.S. 532, 547 (1935). 
national interest being used here in the sense of the common advantage of all the states. ${ }^{147}$ Not only is the national interest placed upon the "scale of decision," but it seems to weigh most heavily of all, even if its only effect is to point to the rule of the one state or of the other as that which should prevail. If what the Court has called the "unifying"14s impulse of the full faith and credit clause be thus regarded as varying in intensity with the demands of the national interest, it follows that, where the national interest does not demand that a choice be made between the policies of several states, it is inappropriate for the Supreme Court to make the choice. However one may regard the results in particular cases, it is submitted that by and large this has been the approach taken by the Supreme Court to questions of full faith and credit in recent decades, and that such an approach is admirably suited to the spirit and needs of our federal system. ${ }^{1 * 9}$

Of course it does not follow that the Supreme Court is the proper agency to implement the full faith and credit clause in this manner. As previously noted, Professor Currie takes the position (1) that the clause is self-executing when one state has a substantial interest and the other has none; and (2) that the clause is not self-executing when the interests of each of several states are sufficient to overcome any objection that the assertion of such interests would be violative of due process-as to such cases the power of Congress to implement the clause is thought by him to be exclusive. Support for this position may be found in a recent historical study by Kurt H. Nadelmann..$^{150}$ It must be noted,

147 If this type of concern is implicit in Broderick v. Rosner, it seems more strongly evident in Order of United Commerical Travelers v. Wolfe, 331 U.S. at 592, 610,621-25. C $f$. Hughes v. Fetter, 341 U.S. 609, 611-12 (1950); Milwaukee County v. MI.E. White Co., 296 U.'S. 268, 276-i7 (1935); Carroll v. Lanza, 349 U.S. 408, 417 (1955) (dissenting opinion).

${ }^{143}$ Hughes v. Fetter, 311 U.S. 609, 612 (1950).

${ }^{149}$ It will be observed that this theory is broad enough to encompass the type of problem involved in cases like John Hancock Mutual Life Ins. Co. v. Yates-that the theory, based upon vindication of the national interest as heretofore defined, justifies the use of the full faith and credit clause to strike down the application of local law, whether or not the forum has substantial contacts with the controversy, when the application of local law would defeat the reasonable expectations of the parties or would otherwise be grossly unfair.

130 Full Failh\& Credil to Judgments and Public Acts, 56 MICH. L. Rev. 33 (1957). Cf. EHrENZWEIG, COAFLICT OF LAWS 27-35 (1959). Both Currie and Nadelmann regard cases of the first category as false-conflict cases. In a constitutional context this terminology seems inapt. Thus in a case of the first category it may be that an otherwise substantial local interest may not legitimately be effectuated because it is not a contemporaneous interest; in such a case a "false" conflict exists only in the sense that the Constitution does not permit the forum to effectuate a very real interest. In cases of the second category; one or more of the several states involved may believe that a "true" conflict exists, but if the Supreme Court of the United States finds in the same situation that the common interest would be served by a common rule, its action may lend itself to rationalization in a number of difierent ways, depending upon the circumstances of the case. If the finding is on grounds which might be appealing to a state court as a matter of englightened self-interest, the finding is in a sense a declaration of paramount federal law that there is no "true" conflict even on the state level. However, as indicated in the text, it is probably more in consonance with the role of federal coercive authority under the full faith and credit clause to rationalize the result as a finding that a particularistic local interest, whether very strong or very weak, should be subordinated to the common interest. 
however, that Nadelmann's conclusion in this instance rests largely on the argument that the draftsmen could not have intended the absurd result which would follow, insofar as public acts are concerned, from a literal reading of the clause in cases of the second type. ${ }^{151}$ But this absurd result is avoided by the kind of reading which, it is suggested, has in effect been given to the clause by the Supreme Court.

In any event, it is unlikely that the Supreme Court will overthrow those decisions in which it took the position, uncritically to be sure, that the full faith and credit clause is self-executing in controversies of the second type, because (1) the evidence of error, if there was error, is tenuous at best; and (2) a sensible solution of the problems involved is feasible through judicial action. Indeed, it is difficult to see how Congress could deal with the subject comprehensively other than by, in effect, directing the Court to continue to act substantially in the same way as it has been acting. The proponents of Congressional intervention under the full faith and credit clause ordinarily are not explicit about what they want Congress to do. ${ }^{152}$ It may therefore be expected that the Supreme Court will continue to restrict local autonomy in choice-of-law matters even when the assertion of a local interest by each of the states involved would not be vulnerable on due process grounds..$^{153}$

The opinion may be ventured that in the implementation of the full faith and credit clause in the general manner suggested the traditional learning of the law of conflict of laws may be most helpful. When the Supreme Court decides that a particúlar choice-of-law rule is desirable in the national interest, it is doing so on grounds which are, or should be, relevant in the decisional process on the state level, quite apart from any constitutional duty of state judges to apply paramount federal law. As indicated earlier, considerations of national interest cannot realistically be ignored in local appraisals of local interest. Putting it another way, the considerations of mutual convenience which are so significant to national states are at least as significant-and undoubtedly a good deal more so- to the subnational units of our federation, in view of their peculiar interdependence and community of interest. ${ }^{154}$

On the other hand, it is obviously desirable that the Supreme Court should

151 Id. at 71-81.

152 Compare the concluding paragraph of note 125 supra.

${ }_{153}$ Professor Currie's approach is not based upon the history of the clause but rests rather upon the argument that the Supreme Court is not competent to resolve true conflict cases, and on the further argument that the political nature of such a task makes it an inappropriate one for a court. As to the first argument, see p. 475 supra. The second seems particularly pointless as applied to the Supreme Court in view of the Court's crucial political function in our federal system.

${ }^{154}$ Cf. YNTEMA, The Historic Bases of Private International Law, 2 Ayr. J. Cosrp. L. 297, 299 (1953); Jackson, Full Faith and Credit-The Lawyers' Clause of the Constitution, 45 Conom. L. REv. 1, 24-34 (1945). It is not suggested that a rational concern with local interest should always or almost always lead to the conclusion that the interest of the forum coincides with the common interest of all the states. It is suggested only that the common interest is a highly relevant factor in the determination of local interest. See note 150 supra. 
proceed with caution in this delicate constitutional area. Despite some unduly narrow holdings in the past, ${ }^{155}$ or perhaps because of them, the Court may be expected to be generally permissive in situations where the common good might be better served by a tighter rein on the propensity to advance purely local interests. Quite apart from the question of the proper role of the Court, one may expect manifestations of judicial diffidence if only because of growing uncertainty about the validity of the "first principles"156 which sustained the earlier holdings. Hence-and this hardly needs to be added-it is not to be assumed by the states that their interests are necessarily served by pushing the effectuation of local policies to the outermost limits set by the Supreme Court.

Some obvious limitations of the theory of governmental interest must be pointed out. There is wide agreement that the implementation of relevant governmental policies may be viewed as the ultimate objective of the law of conflict of laws, and one of the arguments made in this paper is that this objective is defeated by arbitrary limitation of the aspects of governmental interest which a court may consider. It does not follow that in the concept of broad governmental interest, even when it is the enlightened self-interest which is believed to be the proper criterion for the interested forum, we have a ready formula for the solution of particular problems-we have rather a frame of reference for debate on the desirability of particular solutions. Undoubtedly there is a need to reject rigidities of doctrine that preclude rational debate. Beyond that, what is essential is a painstaking "breaking up" of the "larger groupings"157 that constitute the commonly accepted categories of traditional doctrine. This process may be aided, and the basic objective of the law of conflict of laws may be better realized, by general principles or theories that furnish useful guides to decision within the larger frame of reference. ${ }^{158}$ Examples are the common maxim that ordinarily a controversy should be resolved in a manner that conforms with, rather than frustrates, the justifiable expectations of the parties, and theories involving the use of the renvoi or similar devices with a view to eliminating false conflicts. ${ }^{159}$ Any theory is welcome that provides fresh insights into what it is that a court does or should be doing in a conflict situation.

${ }^{155}$ E.g., New York Life Ins. Co. v. Dodge, 246 U.S. 357 (1918).

${ }^{156}$ The phrase was used by Mr. Justice Holmes in Mutual Life Ins. Co. v. Liebing, 259 U.S. 209, 214 (1922).

${ }^{157}$ Cook, An Unpriblished Chapler of the Logical and Legal Bases of the Conflict of Laws, 37 Inc. L. Rev. 418, 422 (1943). Cf. Morris, The Proper Law of a Tort, 64 Harv. L. Rev. 881 (1951); Rheinstein, Book Review, 28 IND. L.J. 443, 449 (1953).

${ }^{158}$ See, e.g., Cheatham \& Reese, Choice of the Applicable Law, 52 CoLon. L. REv. 959 (1952); Neuner, Policy Considerations in the Conflict of Lawe, 6 CANAD. B. Rev. 477 (1942). Cf. Cavers, A Critique of the Choice-of-Law Problem, 47 Harv. L. Rev. 173 (1933).

${ }^{159} \mathrm{Cf}$. Freund, Chief $J$ ustice Stone and the Conflict of Lawe, 59 HARv. L. REv. 1210, 1211-25 (1946); Sohn, New Bases for Solution of Conflict of Lawes Problems, 55 HARv. L. REv. 978 (1942); Griswold, Renvoi Revisited, 51 HARv. L. Rev. 1165 (1938). See also Elrrenzweig, The Lex Fori in the Conflict of Laros-Exception or Rule?, 32 Rocky MT. L. REv. 13, 15 (1959); Briggs, Utility of the Jurisdictional Principle in a Policy Centered Conflict of Laws, 6 Vand. L. REV. 667 (1953). 
A consideration as important as any is that what is proposed as a basis for judicial action be workable. ${ }^{160}$

It was observed earlier that as Professor Currie continues to explore the implications of his method of choice of law he may find that many of the traditional choice-of-law rules are not at all unreasonable in the manner in which they effectuate relevant governmental policies. There is evidence that to some extent he has discovered this already. Ironically, this appears most clearly in his case study of survival statutes, ${ }^{161}$ where his judgments on the "mindless and ruthless machine"162 are particularly severe. In that study he analyzed the possibly competing interests of Arizona and California in a situation where the two states have differing rules as to whether a cause of action survives the death of a tortfeasor; and, as has been noted, ${ }^{163}$ he found that Arizona's interests would be rationally advanced if it looked to the law of the domicile of the decedent and to the law of the situs of his property, observing in this connection that "both domicile and situs have long been recognized in determining the disposition of decedents' property...."164 On the other hand, he found that California's interest, assuming the accident to have occurred in California, would rationally be served by application of the lex loci delicti to determine the issue of survival of the cause of action.

Other choice-of-law rules march through his writings in less familiar garb. It has been seen that his proposals for dealing with the problems suggested by Milliken v. Pratt boil down to the suggestion that a state having a rule of contractual incapacity should look to the law of the domicile on the question of capacity to contract. ${ }^{165} \mathrm{So}$, too, in determining whether a particular act is tortious, he would look, at least in the ordinary case, to the law of the place where the act was committed, since a "rule of conduct" is involved concerning which that place has an obvious interest or policy while the forum qua forum ordinarily has none. ${ }^{166}$ Thus the lex loci delicti is to be applied in what surely must be the great majority of tort cases presenting conflict questions. ${ }^{167}$

\section{CONCLUSTON}

Obviously, this writer has found Professor Currie's writings stimulating and provocative. This is a poor excuse for a paper in which there has probably been excessive emphasis on areas of disagreement and inadequate attention to areas of agreement. The present writer agrees that the implementation of relevant

${ }^{160}$ Cf. Cavers, Book Review, 56 Harv. L. Rev. 1170, 1173 (1943); Cheatham \& Reese, supra note 158 at 976-77.

16110 STAN. L. REv. 205.

162 Id. at 237.

16410 StaN. L. Rev. at 222.

${ }^{163}$ See note 45 supra.

${ }^{165}$ See p. 480 supra:

${ }^{166}$ Currie, On Displacement of the Law of the Forum, 58 Colds. L. Rev. 964, 1021 (1958).

167 Cf. Bartoldos, Conflict of Laws 23-24 (Beale Tr. 1914). 
governmental policies may properly be regarded as the ultimate objective of the law of conflict of laws; he believes that realistic analysis of choice-of-law problems is desirable with a view to detecting and eliminating the false-conflict cases; and he believes that in the cases of true conflict (which are fewer than Professor Currie supposes) the forum should advance its own interests, subject to constitutional limitations. All these points have been made, with varying degrees of explicitness, by previous writers. Professor Currie's contribution, and it is a significant one, is that his own development of these points has, to a high degree, been explicit, dramatic and effective. He has given considerable impetus to the systematic re-examination of the traditional rules along the lines indicated. To this extent his influence will be constructive, and we are much in his debt.

Professor Currie's purported demonstration of the hopeless inadequacy of the traditional methods of the law of conflict of laws has been found unconvincing. As for the method which he himself proposes, it would seem that what he intends primarily is the division of a function which the courts have hitherto exercised alone for the most part. He apparently sees governmental interest as an aggregate of (1) immediate or short-term interests, and (2) general or long-term interests. In advancing governmental interest, he would have the courts concern themselves exclusively with considerations of the first kind, and would leave those of the second kind to legislative action. But even if legislative action were preferable to judicial action in the indicated area, it is not clear why, pending legislative action, the courts should resolve choiceof-law problems in accordance with a standard of governmental interest which is artificially restricted and which, for this reason, cannot rationally advance governmental interest. It seems to this writer that Professor Currie's system would multiply rather than eliminate the so-called false-conflict cases.

Professor Currie's reasons for thus restricting the competence of the courts to deal rationally with the problem of governmental interest seem to stem from the belief that, in the typical conflict case arising in an interested forum, the court is called upon to make a choice between the interest of the state in which it sits and that of some other state. He believes that the courts are not competent to perform this task, and that it is undemocratic to assign this task to them. In this paper an attempt has been made to show that, in what is probably the typical case, the court is not called upon to make a choice between local and foreign interests. The governmental interest of the forum is a composite of particular and sometimes competing interests. If all relevant interests are considered, including those of a long-term or general character, the particular choice-of-law rule that is evolved may be rationally defensible as being advantageous for the forum even though particular local interests may suffer. Thus the problem may be, not whether a particular local interest shall yield to a particular foreign interest, but whether it shall yield to competing local interests. This type of interest-weighing does not seem to be essentially different in kind from that which takes place in a wholly intrastate situation. 
The discussion thus far has been of the interested forum; the role of the disinterested third state in the true-conflict situation presents a special problem. From what he considers to be "the need to seek a rational method for dealing with conflict-of-laws problems"168 and the need to avoid burdening the courts with a function which he believes is not properly theirs, Professor Currie has devised a system which, to use his own language, leaves the disinterested third state in an "impossible position"169 in the absence of Congressional guidance. This is because the system not only fails to provide standards for the solution of such problems but vigorously rejects the interest-weighing which is necessary for their solution, whether conducted on an ad hoc basis, or on the conventionalized basis afforded by a system of formal rules. Guidance from Congress, to be meaningful, would have to take the form of a complete statutory system of choice of law, and it should be quite apparent that such action on the part of Congress is not to be expected. Even if Congress should act in this particular, it is difficult to see how it could produce a result satisfactory to Professor Currie, who frowns alike upon judicial interest-weighing (even by the disinterested forum) because of his belief that this is not a proper judicial function, and upon formal choice-of-law rules because of what he considers to be their "talismanic"170 implications.

Thus, in the true-conflict case, Professor Currie's system leaves the disinterested forum in a position even more "impossible" than he supposes. A proposed system which simply does not take account of an important class of cases-a class moreover which is of peculiar importance in a federation such as the United States-does not commend itself as a basis for the scrapping of the more traditional methods of choice of law.

Finally, the point has been emphasized in this paper that not only should a court concern itself with all relevant aspects of governmental interest, but that it is a mistake to assume, as Professor Currie does, that the traditional learning of the law of conflict of laws has little or no bearing on this problem. It is a mistake to assume that the conflict-of-laws theory and practice of the past represented the product of metaphysical speculations about the nature of law rather than, in the main, the response of men, no less rational than their modern counterparts, to the felt necessities of their times.

Undoubtedly the solutions of the past were imperfect even for those times. The theories have always been imperfect, and a powerful theory exercises a powerful effect on the fashioning of the law. Moreover, the times have changed, and new problems require new solutions. So it is not suggested that the traditional learning of the law of conflict of laws is adequate for contemporary needs. The suggestion is only that it is highly relevant, and that progress in this as in many other areas of the law is most likely to be made by growth from the rich roots of our legal heritage.

${ }^{168} 26$ U. ChI. L. REV. at 11.

${ }^{169}$ See p. 463 supra.

17026 U. CHI. L. REV, at 10. 